\title{
Women in economics: A UK Perspective
}

\author{
Danula K. Gamage \\ Almudena Sevilla \\ Sarah Smith
}

Discussion Paper 20 / 725

23 J uly 2020

2. University of

Department of Economics

University of Bristol

Priory Road Complex

Bristol BS8 1TU

United Kingdom 


\title{
Women in economics: A UK Perspective
}

\author{
Danula K. Gamage
}

QMUL

\author{
Almudena Sevilla \\ UCL and IZA \\ and \\ Sarah Smith \\ Bristol, IFS, CEPR
}

\begin{abstract}
The status of women in economics in the US has come increasingly under the spotlight. We exploit high quality administrative data to paint the first comprehensive picture of the status of women in UK academic economics departments in research-intensive universities. Our evidence indicates that, as in the US, women in economics are under-represented and are paid less than men. The issues facing women in economics in the UK are similar to other disciplines particularly STEM but have received less national policy attention to date. We conclude with a discussion of interventions that might improve the status of women in academia and we present new evidence that a UK academic diversity programme (Athena Swan) has narrowed the gender pay gap at a senior level.
\end{abstract}

Keywords: Gender, Affirmative Action, Academia, Women in Economics, Gender Wage Gap JEL classification: A14

Acknowledgements: We would like to thank the OXREP editors and referees for helpful comments and Shelly Lundberg for sharing the US data. 
The status of women in economics in the US has been making national headlines. In January 2019 the New York Times wrote that female economists were pushing their discipline towards its \#MeToo moment. Women are under-represented in US academic economics departments compared to men, particularly at the senior level (Lundberg and Stearns, 2019). They are also paid less than their male counterparts and are less likely to be promoted (Ceci, at al, 2014; Ginther, and Kahn, 2004, 2009, 2014). A survey of American Economic Association members in 2019 revealed that just 20 per cent of women and 40 per cent of men were happy with the culture in economics (AEA, 2019).

The under-representation of women in economics matters. All disciplines need to draw on the widest possible talent pool. Increasing the share of women in economics is likey to affect the problems that economists works on (Chari and Goldsmith-Pinkham, 2014), the views that economists hold (May et al, 2014; May et al, 2018) and the certainty with which they hold them (Sarsons and Xu, 2015). Arguably diversity particularly matters in economics because of the unique role of economists in public life. The US President is advised by a Council of Economic Advisors, UK Government Departments have chief economists, the Monetary Policy Committee and the Federal Reserve Board make decisions about interest rates that affect the lives of millions. Improving diversity in economics will help to ensure that a diverse group of people helps to shape public policy. ${ }^{1}$

To date, a lot of discussion on the status of women in economics has focused on the US. This paper aims to close this gap. We exploit high quality administrative data for the population of academics to paint the first comprehensive picture of the status of women in academic economics departments in research-intensive ("Russell Group" ${ }^{2}$ ) universities in the UK. This builds on recent survey evidence suggesting that women in economics are under-represented, and are paid less than their male counterparts in the UK even after accounting for socio-demographic, worksplace, and productivityrelated characteristics (Mumford and Sechel, 2019). Our study is complementary to Auriol et al

\footnotetext{
${ }^{1}$ In focusing on gender, we are not assuming that this is the only important dimension for diversity. Ideally, we would take a more intersectional approach but

${ }^{2}$ Within the UK university sector, there is a historic divide between 'old universities' founded before 1992 (pre-1992) and 'new universities' which were former polytechnic colleges and higher education colleges, often focusing on more vocational training, which were granted university status after 1992 as part of a government drive to increase participation in degree-level education (post-1992). The Russell Group is a sub-set of 24 of the most research-intensive old (pre-1992) universities that typically outperform the rest of the sector in national and world rnakings. They are: University of Birmingham, University of Bristol, University of Cambridge, Cardiff University, Durham University, University of Edinburgh, University of Exeter, University of Glasgow, Imperial College London, King's College London, University of Leeds, University of Liverpool, London School of Economics, University of Manchester, Newcastle University, University of Nottingham, University of Oxford, Queen Mary University of London, Queen's University Belfast, University of Sheffield, University of Southampton, University College London, University of Warwick and University of York.
} 
(2020) who use web-scraping to provide broad evidence on women's status in economics across many European countries. We extend these studies in two ways. First, we use an administrative dataset that is comprehensive and covers the entire population of interest. Second, we compare economics with other subjects to to shed light on whether there are general issues that face women in academia (women fare worse than men across all or many academic subjects) and/or a specific problem with the status of women in economics (women fare worse than men in economics; and the gender gaps are greater than in other subjects).

Evidence from the US indicates that the status of women in economics is worse than in other subjects. The gaps in pay and promotion are typically greater than in other maths-intensive disciplines, conditional on measures of productivity ( Ceci, at al, 2014; Ginther and Kahn, 2004, 2009 2014). Ceci, at al (2014) show that there is a bigger deficit between male and female academics' levels of satisfaction in economics than in other disciplines - and that, in contrast with other disciplines, the gap has grown over over time (between 1997 and 2010).

There are reasons why economics might have a particular gender problem (see Bayer and Rouse (2016) for further discussion). Economics has a hierarchical nature in which quality is defined in narrow terms by a "top 5" set of journals (Heckman and Moktan, 2019) and competition for spots in these top journals is fierce. The discipline is also seen by some as having an aggressive culture. In an interview after being awarded the Nobel Prize Esther Duflo reflected abou the tradition of aggression and conflict in the profession: "I think the profession is starting to realize the climate and the way we treat each other is not conducive for having more women in the profession". ${ }^{3}$ There is also, among some economists, a predisposition to place trust in the operation of markets and a belief that discrimination will be competed away that may make them reluctant to acknowledge that there may be persistent gender gaps.

In recent years, there is a burgeoning empirical literature identifying challenges facing women in economics. Women are less likely than men to have papers accepted at conferences (Hospido and Sanz, 2019). Women's papers improve more through the journal process (Hengel, 2017) and their published papers get more citations (Card et al., 2019). Women get asked more questions in economics seminars than men do - and more questions that are deemed to be unfair (Dupas et al., 2020). Papers that women co-author with men count less for the promotion chances of women than men (Sarsons, 2017). Economists on well-used discussion board were also shown to use gendered language (Wu, 2018). Alongside Esther Duflo, other senior figures in the profession, including Ben

\footnotetext{
${ }^{3}$ https://www.cnbc.com/2019/10/14/nobel-economics-prize-winner-esther-duflo-hopes-to-inspire-women.html
} 
Bernanke, Janet Yellen, have identified problems with the culture within economics, including bullying, harassment and discrimination. ${ }^{4}$

These factors could affect women in economics departments outside the US. Economics is an international discipline - we show below that economics departments have a higher share of international academics than other subjects; departments from Europe, Australia, South East Asia, South America and increasingly India, have traditionaly competed on the US “job market” for the best talent; the journals which define quality in the US do the same elsewhere in the world.

However, disciplinary factors might be mitigated by the specific national contexts that universities operate in. The US higher education sector is highly competitive (Aghion et al., 2010) with the largest share of the highest-ranked institutions in the world. US universities also operate largely autonomously from government and compete for resources - and, at least in the case of private institutions, have control over hiring and pay. Competition should reduce discrimination, but this may not be the case if there is implicit bias in the recognition of talent. Autonomy over hiring and pay may increase gender pay gaps (compared to a centralised system) by giving greater weight to, possibly biased, disciplinary norms.

The UK higher education sector (particularly the Russell Group of universities) shares some similarities with the US. The UK has traditionally out-performed other European countries in its share of the highest-ranked universities globally. The UK higher education sector is seen as competitive and there is considerable autonomy in hiring and pay (Aghion et al, 2010). However there are some differences - there is a national pay scale (even if universities often pay off the scale) and progression and promotion processes are typically more centralised within universities than they are in the US.

The emerging picture of female representation in UK economics departments is one of similarity and differences compared to the US. Economics in the UK has a gender problem but in many dimensions, the problem is no worse than in other disciplines. We find that levels of - and trends in - female representation among UK economics faculty are similar to those in the US. Women are underrepresented in economics, particularly at senior levels, with levels of representation closer to STEM than other social science subjects. At the undergraduate level, STEM subjects have made progress in attracting more women while economics has lagged behind. There is evidence of a gender pay gap in economics. At the non-professorial level, conditional on observable characteristics, women are paid on average 6 per cent less than men. This is nearly treble that in STEM and other Social Science subjects, but is similar to Business \& Management. At the professorial level, the gender pay gap in

\footnotetext{
${ }^{4}$ https://www.nytimes.com/2019/01/10/business/economics-sexual-harassment-metoo.html.
} 
Economics, at 3 per cent, is similar to STEM and other Social Sciences and smaller than Business \& Management. There is no evidence of a gender promotion gap in economics, STEM or other social sciences but women lag behind men in promotion in business and management.

We end with a discussion of measures to close gender gaps. Evidence shows that publicising gaps, mentoring junior female faculty, diversity plans and objective assessment criteria can be effective. We present new evidence on a major UK diversity initiative to promote gender equalilty, the Athena Swan accreditation programme, established in 2005 to encourage and recognise commitment to advancing the careers of women in science, technology, engineering, maths and medicine (STEM). In 2015 it was expanded to recognise work undertaken in arts, humanities, social sciences, business and law (AHSSBL). Using a difference-in-differences strategy, we find that department-level accreditation reduces the gender pay gap by half at the professorial level.

\section{UK HIGHER EDUCATION SECTOR}

The UK university sector comprises 158 institutions with degree-awarding powers. Our focus in this study is on 24 research-intensive, "Russell Group”, universities. They are the most similar to the US universities captured in studies on the status of women in economics.

UK universities are relatively strong performers compared to the rest of Europe and the Rest of the World in terms of their position in QS global rankings. They operate in a competitive environment, competing for resources from students and research funding bodies. Russell Group universities see themselves competing in international and national markets (for staff and students) while post-1992 universities focus more on local markets (McCormack et al, 2012). Additional competitive pressure for research-intensive universities comes from regular research ranking exercises (The Research Excellence Framework). ${ }^{5}$

UK universities have a high level of autonomy from the government over budgets (Aghion et al, 2010). ${ }^{6}$ At less than 30 per cent, the UK has the lowest share of public spending on higher education

\footnotetext{
${ }^{5}$ Every five-six years, academics' research is peer assessed to produce a departmental ranking of the quality of outputs, impact and research environment. De Fraja, et al (2019) show that average pay levels and pay inequality in a department are positively related to research performance. In particular, the salary benefits of REF performance are concentrated among the highest paid professors.

${ }^{6}$ Does the university set its own curriculum? • Does the university select its own students or is there centralized allocation? • To what extent does the university select its own professors? • How much does the state intervene in setting wages? - Are all professors with the same seniority and rank paid the same wage? - Does the
} 
of any OECD country. ${ }^{7}$ There is also autonomy over pay. In the study by Aghion et al (2010) no respondent institution in the UK reported that faculty with the same rank/seniority would receive the same pay (the same was true for Belgium, Denmark, Finland, Sweden); by contrast, the same pay is the norm in France, Ireland, Italy, Spain and Switzerland. Prior to 2004, the UK had a nationallydetermined pay scale and there remains a single 51-point national pay spine to which individual institutions link their local pay and grading structures but universities have discretion to place staff posts on the spine and to raise salaries above the top of the scale but this discretion operates within a national framework. Promotion processes are also typically more centralised than in the US and faculty-level committees operating across multiple departments are often the first decision-making committee. 33 per cent of Russell Group managers report that hiring and promotion processes are centralised, compared to 75\% of former polytechnic managers, McCormack et al, 2012).

\section{WOMEN IN UK ECONOMICS: A COMPARISON WITH OTHER DISCIPLINES}

Our analysis exploits comprehensive administrative data covering the population of academic staff in the UK Higher Education Sector during the period 2013-2016 (HESA, 2017). ${ }^{8}$ We focus on academic staff in four major academic subject groups in the 24 Russell Group universities. As well as economics, we choose subject groups that are arguably natural comparators to economics, namely STEM, Social Sciences, and Business Management. For a detailed explanation of how departments are matched to academic subjects please refer to Appendix A. We restrict the sample to academic staff with permanent teaching and research contracts. We have 55,285 observations over the period, 3,865 women (11,975 observations) and 13,030 men (43,310 observations). Table A2 in appendix A lists all the universities in the sample and the academic departments in each of the four major disciplinary groups considered here.

The focus of our analysis is on the representation of women, pay and promotion. Table 1 provides summary statistics for the four subject groups. Table A3 in Appendix A describes in detail how variables are constructed from the HESA original variables. Even at this aggregated level, differences

\footnotetext{
university's budget need to be approved by the government? $•$ What share of the university's budget comes from core government funding? • What share comes from research grants for which the university must compete?

7 https://data.oecd.org/eduresource/spending-on-tertiary-education.htm OECD (2020), Spending on tertiary education (indicator). doi: 10.1787/a3523185-en (Accessed on 17 January 2020)

${ }^{8}$ All statistics in this paper follow a level of aggregation to maintain anonymity of individuals and ensures no personal data or personal sensitive data are identifiable. We follow Higher Education Statistic Agency (HESA) standard rounding methodology to comply with HESA agreement. This implies that (1) Counts of individuals are rounded to the nearest multiple of 5 (2) Percentages based on fewer than 22.5 individuals are suppressed (3) Averages based on 7 or fewer individuals are suppressed. Refer: https://www.hesa.ac.uk/about/regulation/dataprotection/rounding-and-suppression-anonymise-statistics
} 
are clear. Economics has a low share of women - closer to STEM than business or other social sciences. It also has a higher share of professors, again closer to STEM. Salaries are typically high in economics compared to other subjects. This is true at both professorial and non-professorial levels. The share of international staff in economics departments is also the highest at 63 per cent, close to double the share of international staff in STEM and social sciences departments. 
Table 1: Summary Statistics

\begin{tabular}{|c|c|c|c|c|c|}
\hline & (1) & $(2)$ & $(3)$ & $(4)$ & $(5)$ \\
\hline & All & Econ & STEM & $\begin{array}{c}\text { Social } \\
\text { Science }\end{array}$ & $\begin{array}{l}\text { Business a } \\
\text { Manageme }\end{array}$ \\
\hline \multicolumn{6}{|c|}{ Panel A: Department Characteristics } \\
\hline Prop. women & 0.226 & 0.200 & 0.165 & 0.421 & 0.331 \\
\hline Prop. professorial staff & 0.340 & 0.353 & 0.355 & 0.297 & 0.304 \\
\hline Prop. part-time staff & 0.060 & 0.059 & 0.060 & 0.060 & 0.052 \\
\hline Prop. female Head of school & 0.126 & 0.062 & 0.101 & 0.203 & 0.221 \\
\hline Prop. international staff & 0.371 & 0.631 & 0.351 & 0.300 & 0.494 \\
\hline REF GPA & 3.14 & 3.08 & 3.18 & 3.05 & 3.02 \\
\hline Average department size & 45 & 37 & 47 & 29 & 74 \\
\hline Number of Departments & 312 & 21 & 210 & 57 & 24 \\
\hline Number of Universities & 24 & 21 & 24 & 23 & 24 \\
\hline
\end{tabular}

Panel B: Individual characteristics by rank

\section{Non-Professors}

\begin{tabular}{lccccc} 
Log real wage & 10.85 & 10.86 & 10.85 & 10.82 & 10.84 \\
Prop. women & 0.259 & 0.244 & 0.201 & 0.428 & 0.397 \\
Prop. part-time & 0.044 & 0.022 & 0.048 & 0.043 & 0.033 \\
Average age & 43 & 40 & 43 & 42 & 41 \\
Average years' tenure & 10 & 8 & 11 & 8 & 7 \\
Number of individuals & 11,645 & 645 & 7,855 & 1,535 & 1,730 \\
Number of observations & 35,235 & 1,845 & 24,065 & 4,510 & 4,815 \\
\multicolumn{1}{c}{$\quad$ Professor } & & & & & \\
Log real wage & 11.28 & 11.42 & 11.25 & 11.27 & 11.41 \\
Prop. women & 0.142 & 0.138 & 0.113 & 0.299 & 0.204 \\
Prop. part-time & 0.093 & 0.142 & 0.084 & 0.104 & 0.116 \\
Average age & 52 & 52 & 52 & 53 & 52 \\
Average years' tenure & 15 & 12 & 16 & 13 & 10 \\
Number of individuals & 6,240 & 390 & 4,495 & 655 & 750 \\
Number of observations & 20,050 & 1,160 & 14,735 & 1,935 & 2,220
\end{tabular}

Notes: Source 2013-2016 HESA dataset. Panel A presents average departmental characteristics. Panel B shows the average individual characteristics. Annual wages are censored at the top and the bottom $1 \%$ salaries earned to prevent extreme outliers affecting mean salaries and are adjusted using 2016 CPI index. REF GPA refers to the score (out of 4) given to each department in the last Research Excellence Framework for the quality of its research. See Appendix A Table A3 for a description of the variables. 


\section{III.i Female representation}

The share of women in economics departments has increased over the past decades (see CWEN, 2015 for Canada, Lundberg and Stearns, 2019, for the US, and Corsi, et al, 2017, for Italy). However progress has been slow and women remain under-represented. Figure 1 uses data from the 2000-2016 Royal Economics Society Women's committee survey on Gender Balance of Academic Economics to provide a historical benchmarking of the UK experience to that of the US (see Figure 1 in Lundberg and Stearns, 2019). The trend is very similar across the two countries. The share of female professors has almost doubled, increasing from 7.5\% in 2000 to $12.7 \%$ in 2016 in the UK and from $6.7 \%$ to $11.9 \%$ in the US, while the at the assistant professor leel the increases have been from 27.8 to $32.1 \%$ in the UK and from $21.2 \%$ to $25.5 \%$ in the US. ${ }^{9}$ Despite these increase, the share of women remains low. Women are under-represented at all levels and particularly at senior level. The modest increases at the lower levels suggests that it will be a long time before parity is achieved and Lundberg and Stearns argue that progress has stalled in the US. By way of comparison, Auriol et al (2019) report levels for Europe of 39\% women in entry-level positons (36\% at the top 100 institutions), 33\% (32\% at top 100) at associate level position and 23\% (20\%) at professorial level. The under-represesentation of women in economics is a discipline-wide problem.

Figure 1: Trends in female representation in Economics

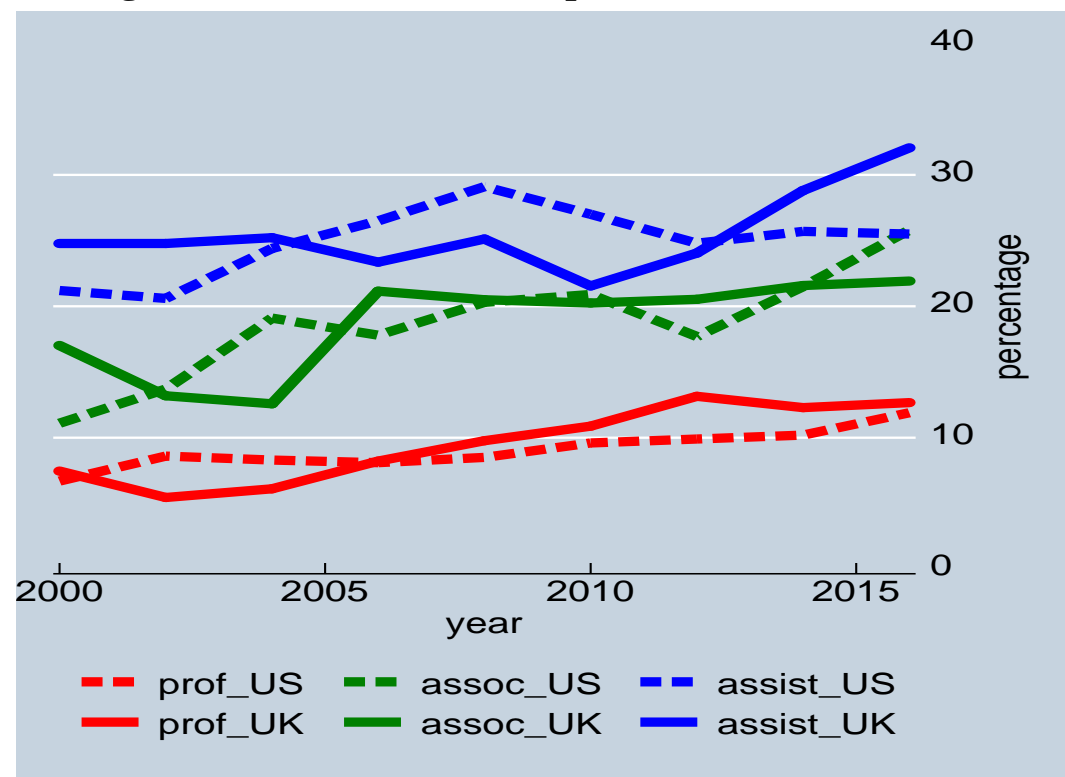

Notes: UK data obtained from the 2000-2016 Royal Economics Society Women’s committee survey on Gender Balance of Academic Economics for the 24 Russell Group Universities (see Tenreyro, 2017). US data are taken from Lundberg and Stearns (2019), and covers the Chairman's group of 43 universities. 'prof' refers to full professor, 'assoc' refers to the Associate professor and 'assist' refers to the Assistant professor

\footnotetext{
${ }^{9}$ Comparison of balanced samples for 1996 (Mumford, 1997) and 2016 (Tenreyro, 2017) using the RES data shows that the proportion of female economists increased from less than one-in-six in 1996, to more than onein-four in 2016. Our numbers are smaller as a result of restricting the sample to Russell Group Universities.
} 
Table 2 compares economics with the three other subject groups and further compares the UK with the US (see Figure 3 in Lundberg and Stearns, 2019). The level of female representation is lowest in some science departments (chemistry and engineering, and maths/physics/computer sciences); female representation in economics is closer to science levels and is well below other social sciences. As in the US, the proportion of women in Social Sciences (42 per cent) and Business Management (33 per cent) is almost double the share of women in Economics (20 per cent), and STEM (16 per cent).

Multiple initiatives in the UK and other countries, including many government-funded programmes, have focused on the need to encourage female take-up of STEM subjects (see House of Commons, 2016, for a summary). These initiatives have succeeded in increasing the share of women at the start of the pipeline in some STEM subects. The share of women studying for a biology degree is 60 per cent; in chemistry, it is 42 per cent; in maths, it is 36 per cent, although it remains low in physics (21 per cent) and computer science (14 per cent). The share of women in economics at undergraduate level is also low at 28 per cent. Only relatively recently has attention turned to the importance of encouraging more women to study economics at undergraduate level (Avilova and Goldin, 2019; Crawford et al, 2018). We would argue that the persistent under-representation of women - and the lack of diversity more generally - needs to be given the same kind of attention as was given to women in STEM, given the role of economists in policy-making.

Table 2: Female Representation in the US and the UK across academic subjects

Economics

Chemistry and Engineering

Maths/Physics/Computer Science

Biology/Earth Sciences

Politics and International Studies

Psychology

Sociology

\begin{tabular}{ccccc}
\hline \multicolumn{2}{c}{ UK } & \multicolumn{3}{c}{ US } \\
\hline Prof & Non-Prof & Prof & Assoc & Assist \\
\hline 0.138 & 0.245 & 0.099 & 0.177 & 0.248 \\
0.093 & 0.170 & 0.096 & 0.162 & 0.250
\end{tabular}

0.094

0.164

0.101

0.181

0.227

0.162

0.289

0.167

0.302

0.332

0.191

0.341

0.222

0.351

0.404

0.288

0.461

0.327

0.438

0.503

0.543

0.333

0.541

0.636 for the 24 Russell Group universities and are taken from the HESA dataset as explained in Appendix A. We use our sample to construct this table, as explained in section III, and additionally introduce academic staff in psychology departments for comparison purposes. 'Prof' refers to full professor, 'Assoc' refers to the Associate professor, 'Assist' refers to Assistant professor and 'Non-Prof' refers to Aggregation of Associate and Assistant professors.

\section{III.ii Gender pay gaps}

Table 3 summarizes average real annual earnings (£) for the four subject groups, by academic rank. Two things stand out. First, salaries in economics are consistently higher than those in the other 
subject groups, although close to those in Business \& Management. ${ }^{10}$ Second, women earn less than men in all subject groups and in both ranks. The raw gender pay gap is particularly acute at the professorial level, and especially for individuals in the highest paid disciplines (Economics and Business Management).

Table 3: Average salaries ( $£, 2016$ prices)

\begin{tabular}{|c|c|c|c|c|}
\hline & \multicolumn{2}{|c|}{ Non-Professors } & \multicolumn{2}{|c|}{ Professors } \\
\hline & Female & Male & Female & Male \\
\hline Economics & 50,937 & 54,385 & 87,339 & 95,260 \\
\hline No. of Individuals & 165 & 480 & 60 & 330 \\
\hline No. of Observations & 450 & 1,395 & 160 & 1,000 \\
\hline Business and Management & 49,808 & 54,242 & 85,760 & 94,009 \\
\hline No. of Individuals & 680 & 1,050 & 155 & 600 \\
\hline No. of Observations & 1,910 & 2,905 & 455 & 1,765 \\
\hline STEM & 50,695 & 52,908 & 74,942 & 78,689 \\
\hline No. of Individuals & 1,665 & 6,190 & 555 & 3,940 \\
\hline No. of Observations & 4,825 & 19,235 & 1,665 & 13,070 \\
\hline Social Science & 49,744 & 51,679 & 76,481 & 80,835 \\
\hline No. of Individuals & 665 & 875 & 200 & 455 \\
\hline No. of Observations & 1,930 & 2,580 & 580 & 1,360 \\
\hline
\end{tabular}

Notes: Source HESA data 2013-2016. Earnings distributions are censored at the top and the bottom 1\%.

We estimate a standard "wage" equation to determine the extent to which there is a gender pay gap when we include controls:

$$
\log _{-} w_{i j s t}=\alpha+\beta F_{i}+X^{\prime}{ }_{i t} \gamma+\pi_{t}+\eta_{j}+\mu_{s}+\varepsilon_{i j s t}
$$

The dependent variable is the $\log$ real annual salary $\left(w_{i j s t}\right)$ of individual $i$ in university $j$ in subject $s$ at time t. $F_{i}$ is a binary indicator $=1$ for female academics. $\beta$ is our main coefficient of interest. The vector $X_{i t}$ includes time-varying individual characterictics. We do not have any information on children, which have been shown to affect earnings, nor direct measures of productivity, but we include variables that are correlated with productivity in the literature, i.e. age and age squared to proxy for experience, and employment characteristics such as tenure, tenure squared and a part-time indicator (Mumford and Sechel, 2019 and Blackaby, at al, 2005). Panel B in Table 3 shows all the

\footnotetext{
${ }^{10}$ These figures are consistent with Table A.1 in Mumford and Sechel (2019) who report average gross annual earnings of 73,109 for male economists and 60,418 for female economists from a 2016 survey of 668 academic staff working in Economics departments in the UK.
} 
summary stats for these variables for each discipline, and Table A3 in Appendix A describes how these variables are constructed. We additionally control for year dummies $\left(\pi_{t}\right)$, and university dummies $\left(\eta_{\mathrm{j}}\right)$. When appropriate (in STEM and Social Sciences disciplines) we also control for academic subjects within the subject groups $\left(\mu_{s}\right)$. We estimate this equation by subject group, separately for professors and non-profiessors. $\varepsilon_{i j s t}$ is the error term and is clustered at the department level.

Table 4: The gender pay gap

Dependent variable $=$ Ln(real annual salary)

\begin{tabular}{|c|c|c|c|c|}
\hline & \multicolumn{2}{|c|}{ Non-Professors } & \multicolumn{2}{|c|}{ Professors } \\
\hline & $\begin{array}{c}(1) \\
\text { No controls }\end{array}$ & $\begin{array}{c}(2) \\
\text { Controls } \\
\end{array}$ & $\begin{array}{c}(3) \\
\text { No controls } \\
\end{array}$ & $\begin{array}{c}(4) \\
\text { Controls } \\
\end{array}$ \\
\hline \multicolumn{5}{|l|}{ Panel A- Economics } \\
\hline Female & $\begin{array}{c}-0.058^{* * *} \\
(0.020)\end{array}$ & $\begin{array}{c}-0.058^{* * *} \\
(0.010)\end{array}$ & $\begin{array}{c}-0.082 * * \\
(0.033)\end{array}$ & $\begin{array}{l}-0.034 \\
(0.027)\end{array}$ \\
\hline No. of Individuals & 645 & 645 & 390 & 390 \\
\hline No. of Observations & 1,845 & 1,845 & 1,160 & 1,160 \\
\hline R-squared & 0.013 & 0.491 & 0.013 & 0.446 \\
\hline \multicolumn{5}{|c|}{ Panel B- Business \& Management } \\
\hline Female & $\begin{array}{c}-0.067^{* * *} \\
(0.013)\end{array}$ & $\begin{array}{c}-0.053^{* * *} \\
(0.010)\end{array}$ & $\begin{array}{c}-0.084^{* * *} \\
(0.020)\end{array}$ & $\begin{array}{c}-0.054^{* * *} \\
(0.014)\end{array}$ \\
\hline No. of Individuals & 1,730 & 1,730 & 750 & 750 \\
\hline No. of Observations & 4,815 & 4,815 & 2,220 & 2,220 \\
\hline R-squared & 0.020 & 0.467 & 0.021 & 0.425 \\
\hline \multicolumn{5}{|l|}{ Panel B - STEM } \\
\hline Female & $\begin{array}{c}-0.039 * * * \\
(0.005)\end{array}$ & $\begin{array}{c}-0.022^{* * *} \\
(0.004)\end{array}$ & $\begin{array}{c}-0.046^{* * *} \\
(0.009)\end{array}$ & $\begin{array}{c}-0.036 * * * \\
(0.006)\end{array}$ \\
\hline No. of Individuals & 7,855 & 7,855 & 4,495 & 4,495 \\
\hline No. of Observations & 24,065 & 24,065 & 14,735 & 14,735 \\
\hline R-squared & 0.008 & 0.478 & 0.005 & 0.307 \\
\hline \multicolumn{5}{|c|}{ Panel D - Social Science } \\
\hline Female & $\begin{array}{c}-0.035^{* * *} \\
(0.011)\end{array}$ & $\begin{array}{c}-0.020^{* * *} \\
(0.006)\end{array}$ & $\begin{array}{c}-0.052^{* * *} \\
(0.014)\end{array}$ & $\begin{array}{c}-0.033 * * * \\
(0.009)\end{array}$ \\
\hline No. of Individuals & 1,535 & 1,535 & 655 & 655 \\
\hline No. of Observations & 4,510 & 4,510 & 1,935 & 1,935 \\
\hline R-squared & 0.008 & 0.534 & 0.016 & 0.432 \\
\hline
\end{tabular}

Note: Source HESA data 2013-2016. Earnings distributions are censored at the top and the bottom 1\% salaries. Controls are age, age squared, tenure, tenure squared, part-time indicator, university fixed effects, and time fixed effects. Subject fixed effects are included when appropriate (i.e. for STEM and Social Sciences with more than one subject). Robust standard errors are clustered at the department level are shown in parentheses. ${ }^{* * *} \mathrm{p}<0.01,{ }^{* *} \mathrm{p}<0.05,{ }^{*} \mathrm{p}<0.1$ 
Columns 1 and 3 in Table 4 present benchmark estimates of the raw gender pay gaps - confirming that they are highest in Economics and Business \& Management. Adding controls has little effect on the magnitude of the gender pay gaps in non-professorial salaries. At this lower level, the conditional gender pay gap in economics (6\%) is similar to that in Business \& Management (5\%) and almost treble that in STEM and the other Social Sciences (2\%). At the professorial level, the conditional gender pay gap narrows in economics and, at 3\%, is the same as in STEM and other Social Sciences, albeit less precisely estimated. At the professorial level, the conditional gender pay gap is greatest in Business \& Management (5\%).

These estimates confirm the findings of previous studies that there are gender pay gaps in academia even when comparing like with like. The estimated gaps in economics are smaller than that reported by Mumford and Sechel (2019) who show a gap of 12.7\% after including demographic, productivity, workplace and labor market related characteristics for a sample of 367 academic staff in UK Economics departments in 2016. However, their study is not directly comparable because of the selfselected nature of their sample. Ward (2001) analyses a survey of academic staff in five of the eight old Scottish Universities in 1996 showing that medicine has the highest raw gap, followed by Science and Social Science disciplines. In the US, Ceci, et al (2014) use data on the 2010 Survey of Doctorate Recipients show that the gender gap among economics professors is worse than that for professors in Engineering, Geoscience, and Physical Science and associate professors in Life Sciences. Tao (2018) uses several waves of data from the National Science Foundation from 2003 to 2013 to document that women earn about 5 per cent less then men after controlling for demographic, educational, productivity and employment-related characteristics.

\section{III.iii Gender promotion gaps}

Our estimates of gender pay gaps by academic grade (professor/ non-professor) may be misleading if women take longer to reach higher grades. US studies have found a significant gender promotion gap in economics, albeit one that is narrowing over time. Ginther and Kahn (2004) find a 18 ppt gap in achieving tenure within 10 years for the 1972-91 cohorts of PhD students; Ginther and Kahn (2006) find a 12 pppt tenure gap for the 1981 - 2003 PhD cohorts; Kahn (2020) finds a 4.5 ppts tenure gap (cohorts).

Figure 2 plots hazard rates for promotion to professor (from non-professor), by subject group, for men and women. We expand the dataset to create age histories back to age 30 and include promotions to non-RG universities. Estimates from a cox proportional hazards model, including controls for university and subject are presented below. The promotion rate for women is below that for men in economics - including controls, the estimates indicate that the promotion rate for women is around 80 
per cent that for men. Promotion rates are also lower for women in social science and business \& management. The gender gap is greatest - and statistically significant - for business \& management. In STEM, the promotion rate for women is greater than that for men, but the gap is not statistically significant.

Figure 2: Promotion to Professor
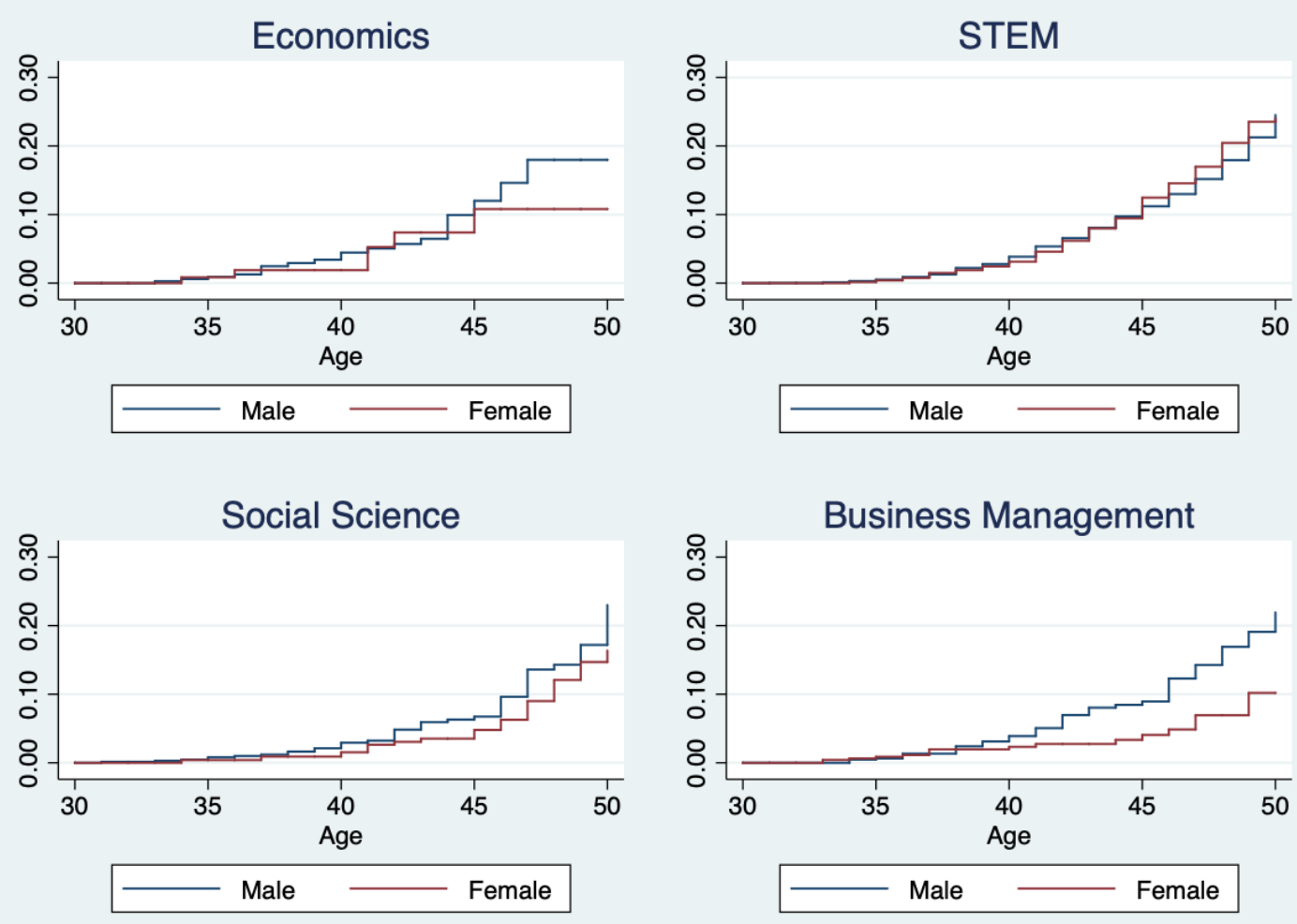

\begin{tabular}{lcccc}
\hline Hazard ratio & Econ & B\&M & STEM & SocSci \\
\hline & & & & \\
(A) Raw data & 0.740 & 0.477 & 1.020 & 0.687 \\
& $(0.338)$ & $(0.173)$ & $(0.103)$ & $(0.173)$ \\
(B) Including covariates & 0.820 & 0.506 & 1.118 & 0.822 \\
& $(0.393)$ & $(0.153)$ & $(0.116)$ & $(0.218)$
\end{tabular}

Notes: Source 2013-2016 HESA dataset. Graphs plot the hazard rate. The table presents the female-male hazard ratio. Covariates are university and subject. 


\section{Closing gender gaps in economics and academia}

Our results show that women lag behind men in academia - in levels of representation, pay and, for some, promotion. While it is important to identify problems, it is also important to offer solutions and to identify practical measures that might help to improve women's status in academia. In this section we review a growing literature offering causal evidence on policy interventions that work - as well as on policy interventions with mixed results (see also Buckles, 2019 for discussion of initiatives to close the gender gap in economics and Behavioural Insights Team, 2018, for a broader review). We focus our discussion on policy interventions designed to close the gender gap among academics, rather than policies to encourage more women to study economics. The latter is an important but separate challenge. We take for granted that generous maternity provision and flexible working arrangements are importantt (see Epifanio and Troeger, 2019).

\section{IV.i What has worked well?}

a. Data

The first step in tackling a problem is to admit that there is a problem. Professional societies' Women's Committees have spent years collecting and publishing data showing the underrepresentation of women in the economics profession (see Tenreyro, 2017, for the UK). Many initiatives to address gender gaps have followed from the growing recognition that there is persistent under-representation of women in economics, particularly at higher levels, that cannot be attributed to a cohort effect.

Is there also a direct effect from collecting and publishing data? Some organisations have actively collected evidence out of a desire to identify - and then address - their gender gap problem. Econometric analysis of academics' pay commissioned by the LSE's EDI task force, for example, led directly to a pay increase for women (see Bandiera et al, 2016) ${ }^{11}$ Externally-imposed requirements to publish pay gap information can also bring about change. Bennedsen et al (2019) showed that the requirement for Danish firms to publish gender pay gap information resulted in a narrowing of the gap for firms who had to publish (largely achieved through a reduction in pay increases for men). -More work is required to understanding whether the mechanism is to highlight a problem that organisations were unaware of or to shame them into taking action.

\footnotetext{
${ }^{11}$ https://www.timeshighereducation.com/news/london-school-of-economics-give-femaleacademics-pay-rises-close-gap-men
} 
b. Mentoring and networking

Professional societies in economics have run mentoring programmes for junior female academics for nearly twenty years. CSWEP introduced a programme for US-based junior women in 2004, followed by the RES for UK-based academics in 2012 and by the EEA for European-based academics since 2013. The mentoring programmes run by these different organisations follow a broadly common format with a mix of plenary sessions delivered by senior (female) academics covering different aspects of academic life (getting published, writing grants, networking, work-life balance, teaching) and small-group research-focused sessions providing detailed feedback on junior academics' papers. Blau et al (2010) evaluated outcomes for the first three cohorts of mentees who took part in the CSWEP mentoring programme. Places on the over-subscribed programme were allocated at random, allowing an RCT-evaluation comparing outcomes for 205 mentees who were in the treatment group and 163 mentees who acted as a control. The evaluation found that participating in the programme had a positive effect on the number of publications and grants. A follow-up study (Ginther et al 2020) showed that the longer-term outcomes were also positive with participants enjoying a significantly higher probability of tenure at a higher-ranked institution (defined as $50+$ ), driven by a higher probability of more grants and better publications.

This is a positive story for individuals who take part in the mentoring programme offered by CSWEP. It would be interesting to see whether the UK and European schemes have similar effects and also to understand the channel(s) through which mentoring achieves the positive effects. It may work by providing information to junior academics (eg about the journal publication process) and/or by offering (senior) female role models and/or by helping junior academics to build networks. Ductor et al (2018) show that male academic economists connect to a larger number of co-authors, while women have smaller networks, i.e. they are more likely to co-author with the same people (and the co-authors of co-authors). These smaller networks, they argue, may explain why women typically write fewer papers than their male counterparts.

\section{c. Diversity plans}

Hospido et al (2019) report on a successful diversity action plan introduced by the European Central Bank to close the gender gap in promotion to senior management. In 2010, the ECB launched a diversity initiative with a clear public statement, a well-defined focus (attracting female candidates, enhancing the internal pipeline of female candidates, facilitating work-life balance and increasing accountability and commitment) and a specific gender target (35\% by 2019) for managerial positions. There was an increase in the representation of women on selection panels (allowing the inclusion of a member from another business area if this enhances the gender diversity of the selection committee) and a mentoring programme. The plan succeeded in closing the gender promotion gap from 35\% to 
8\% with many more women being encouraged to apply for promotion. This is an important issue in academia - analysing French data, Bosquet et al (2019) report that women are 50\% less likely to be promoted, and that $50-75 \%$ of this gap can be explained by the fact that they are less likely to apply for promotion (the rest of the gap is attributable to productivity differences). This is a very promising initiative which has had a sizeable impact. The fact that there are several elements makes it hard to know what exactly accounted for the success, although Hospido et al (2019) rule out that increasing the number of women on selection committees had an effect. Behavioural Insights Team (2019) emphasize specific targets as having a positive effect.

\section{d. Objective assessments}

Reviewing policies to reduce gender gaps, the Behavioural Insights Team report also highlighted the importance of objective assessments (covering skill-based tasks and structured interviews and transparency in promotion and pay and reward schemes) among their "policies that work". There are many dimensions in which academic recruitment, promotion and pay processes deviate from this ideal, not least in the (disproportionate) role played by subjective assessments. The evidence (Sarsons, 2017) that women who co-author with men face a lower promotion probability is symptomatic of a process in which potentially gender-biased subjective judgements can affect outcomes.

Evidence suggests that two (other) sources of information used in the assessment process may be subject to gender bias.

The first is student evaluations. Evidence from France (Boring, 2017), the Netherlands (Mengel et al, 2019) and the US (MacNell et al, 2015) shows that female academics receive worse evaluations from male students despite there being no difference in objective performance. In the recent AEA climate survey, 47 per cent of female academics said that they had personally experienced discrimination with regard to course evaluations (compared to 8 per cent of male). Promisingly, a recent study by Boring and Philippe (2017) showed an informational treatment (telling students that previous cohorts of males were biased against female instructors) caused male students to increase their scores. A simple normative treatment asking students to be aware of possible biases had no effect.

The second is assessor letters which play an important role in hiring and promotion decisions. There is no evidence for economics but a number of studies highlight differences in the language used in reference letters written for men and women. Letters written for women have more "doubt-raisers”, i.e. phrases which suggest some element of doubt about the candidate and fewer brilliant assessments (Dutt et al, 2016; Schmader et al, 2007; Madera et al, 2009; Madera et al, 2019). Williams and Ceci (2015) find that academics generally show a preference for hiring a woman over a man in STEM 
subjects, with the exception of economics. However, there is no preference for hiring a woman over a man perceived to be more qualified - and slightly worse student evaluations/ letters of assessment may tip the balance.

\section{IV.ii What has worked less well?}

\section{a. Diverse selection panels}

Many institutions, when faced with gender gaps in promotion and hiring, try to address the problem by instituting diverse selection panels. However, there is no evidence that diverse selection panels have a positive effect on women's success. As already reported, Hospido et al (2019) report that an increase in the share of women had no effect on female promotion in the ECB. Bagues and Zinovyeva (2017) similarly find that more women on academic selection panels do not increase the quantity or quality of women who are chosen. Female evaluators are not significantly more favourable towards women while male evaluators become less favourable to women. In their study of implicit bias, MossRacusin (2012) et al, show that women are just as likely to show bias against women than men are. The Behavioural Insights Team report (2019) finds that no systematic evidence that diversity training has a positive effect on outcomes for women.

Moreover, the push to have more panels may harm some women's promotion prospects by requiring them to sit on more panels and spend more time on administrative tasks that attract lower rewards in academia compared to prestigious research publications. Guarino and Borden (2017) find that women do more academic service - particularly internal service - than their male counterparts (and that the disparity is particularly great for female professors who may lose out on pay increases if not promotion). In a novel lab experiment, Babcock et al (2019) show that, even in the absence of diversity initiatives which may increase the amount of time women devote to administrative tasks, women are more likely to be asked to volunteer for unrewarded public service tasks - and are more likely to say yes to such requests.

Women taking on major administrative roles can have a positive effect on outcomes. Langan (2019) reports that having a female head of department is associated with a reduction in gender wage gaps in the US. Analysis of department-level HESA data points to similar effects in the UK. In social science, STEM and business, female heads are associated with a higher female share and a smaller gender pay gap. Of course this evidence is not causal - there is a negative association in economics between having a female head of department and female representation; this may indicate an attempt to hire a female department head to address a gender problem. 
b. Stopping the clock

In some cases, policies that are intended to support women and to close gender gaps can actually backfire. Antecol et al (2018) report on the effects of a "stop the clock" policy, ie a policy of granting additional time to fixed tenure track periods for people who have children. Such policies were applied blindly such that all such new parents benefited, irrespective of whether they actually did any childcare, and turned out to benefit men much more than it did women. Such policies were associated with a 19 percentage-point rise in the probability that a male economist would earn tenure at his first job - and a 22 percentage points fall for women. In essence, the men used the extra time to publish more and raised the bar for women. This evidence is instructive in that it shows the potential pitfalls that may arise; however, it does not mean that it is impossible to find policies that help carers deal with the consequences of caring for their careers. Policies that appropriately lower thresholds may offer an alternative way forward.

\section{IV.iii Athena Swan}

Finally, we present new evidence on the effects of a unique UK initiative; the Athena Swan Charter. This was established in 2005 to advance the careers of women working in STEM disciplines in higher education. In 2015 it was expanded to recognise work undertaken in arts, humanities, social sciences, business and law (AHSSBL). Athena Swan awards are given - at bronze, silver or gold level - to institutions that are committed to gender equality. The application process requires an institution to conduct a comprehensive audit of gender equality, and to make proposals for change, i.e. measures to overcome gender equality challenges (eg more transparent process for appointing heads of departments, career track schemes to help women to move from fixed-term contracts to permanent contracts, support with staff review and development processes). There are no explicit targets for female employment or wages, nor does Athena Swan dictate specific interventions that universities need to put into place. There is no requirement for institutions to make a submission although it is increasingly important for funding applications (Gregory-Smith, 2018); and it is a sign of an institutional commitment to gender equality. There is a two-step accreditation process - first at the university level and then, once the university is accredited, departments can apply for accreditation. Preparing the departmental-level submission is a lengthy and relatively costly process drawing in several $(7$ - 13) people within a department to form a self-assessment team to prepare the required quantitative and qualitative data and to do the analysis and self-reflection for a successful submission. The self-assessment team is required to collect evidence on the representation of women at different levels and on gender differences in recruitment, retention, progression/promotion and to consider the impact of practices (seminars, social events) and policies (flexible working, training etc). In total the process of putting together a submission is typically estimated to take eighteen months. Gamage and 
Sevilla (2019) show that university accreditation had a modest effect on closing the gender pay gap; they found little effect of university-level accreditation on female representation. Here we focus on department-level accreditation.

We study the relationship between department-level accreditation and gender pay gaps. We merge the 2009-2016 individual-level data with a self-constructed dataset containing information on accreditaton dates obtained from the published information in the Athena Swan booklets (see Appendix B for a detailed description of how the data set is constructed. Unfortunately we only observe the outcomes of successful applications). As in our main analysis we restrict the sample to academic staff with permanent teaching and research contracts and we focus on 155 (out of 182 STEM) departments in the 24 Russell Group universities that have received accreditation. The focus on STEM is because of the more widespread accreditation among STEM departments in our dataset the charter was only extended to AHSSBL in 2015 (see Appendix B Table B4 for a comparison of data for accredited/ non-accredited STEM departments). Our sample has 67,365 observations for 2,085 female academics (10,360 observations) and 10, 330 male academics (57,005 observations).

We employ a difference-in-differences analysis. We compare female pay (our treatment group) to that of males (our control group) and use an event study approach to look at what happens to female pay relative to male pay for each year before/after Athena SWAN accreditation, ${ }^{12}$ i.e.:

$$
\begin{gathered}
\log w_{i j s t}=\alpha+\beta F_{i}+\sum_{n=-5}^{n=-2} \gamma_{n} A_{j s t+n}+\sum_{n=0}^{n=6} \gamma_{n} A_{j s t+n}+ \\
+\sum_{n=-5}^{n=-2} \gamma_{n} F_{i} \times A_{j s t+n}+\sum_{n=0}^{n=6} \gamma_{n} F_{i} \times A_{j s t+n}+X_{i t} \varphi^{\prime}+\pi_{t}+\mu_{s}+\eta_{j}+\gamma_{\mathrm{j}} \mathrm{t}+\varepsilon_{i j s t}
\end{gathered}
$$

where $\log _{-} w_{i j s t}$ is the log real salary (using 2016 as the base year) of individual $i$ in a subject $s$, university $j$, and year $t$. $A_{j s t}$ is a binary indicator that takes the value 1 for a subject $s$ that is awarded Athena Swan accreditation in year $t$, and 0 otherwise. We interact this with an indicator for female. $X_{i s j t}$ is a vector of characteristics that are known to be correlated with wages as in Equation 1 . The coefficients of interest are related to these interaction terms - ie the evolution of female pay relative to male pay. We also include university dummies $\eta_{j}$, subject dummies $\mu_{s}$ and time dummies $\pi_{t}$. The university and subject dummies addresses unobserved and time-invariant university-and subjectspecific factors that are potentially correlated with wages such as the fact that higher ranked universities pay higher salaries. The time dummies accounts for aggregate level shocks potentially impacting wages in academia, as could have been the case with the 2008-2009 downturn. Universityspecific time fixed effects $\left(\gamma_{\mathrm{j}} \mathrm{t}\right)$ capture a variety of unobserved time-varying university-level traits that might remain unaccounted for (including university accreditation).

\footnotetext{
${ }^{12}$ We cannot rule out that Athena Swan accreditation might affect male wages but the focus of our analysis is on whether the effect is different for women and men.
} 
We estimate the equation separately for professors and non-professors. The main coefficients of interest are plotted in Figure 3 below. The full regression results are given in the Appendix B Table B5. We see that, whereas women's pay in non-professorial ranks is not affected, relative to the pay of men, the pay of female professors increases relative to that of their male counterparts after Athena Swan accreditation. The overall effect is equivalent to halving the gender wage gap from 5 percentage points to less than 3 percentage points. Of course, there may be some limitations in giving this result a causal interpretation. Athena Swan accreditation is an endogenous decision by departments - they choose whether and when to apply. Another potential concern is that there is a substantial time lag between starting to apply and completing the submission due to the process of conducting an internal audit and pulling together the necessary quantitative and qualitative data that go into a submission. For both of these reasons, we might expect to see differential trends in male/female pay (i.e. non-zero coefficients) in the pre-period but there is no evidence of this in the data. Indeed the date of accreditation (or at least the date of submission) appears to be the key turning point in the gender pay gap for professors. One reason may be that drawing up a plan for improving gender equality is likely to come towards the end of the process, close to the date of submission. Departments are assessed on their progress when they have to re-apply for accreditation after three years and so will be looking forward from the date of submission to work towards fulfilling the promises that they have made.

Figure 3: Evolution of female pay relative to male pay, before/ after Athena Swan accreditation

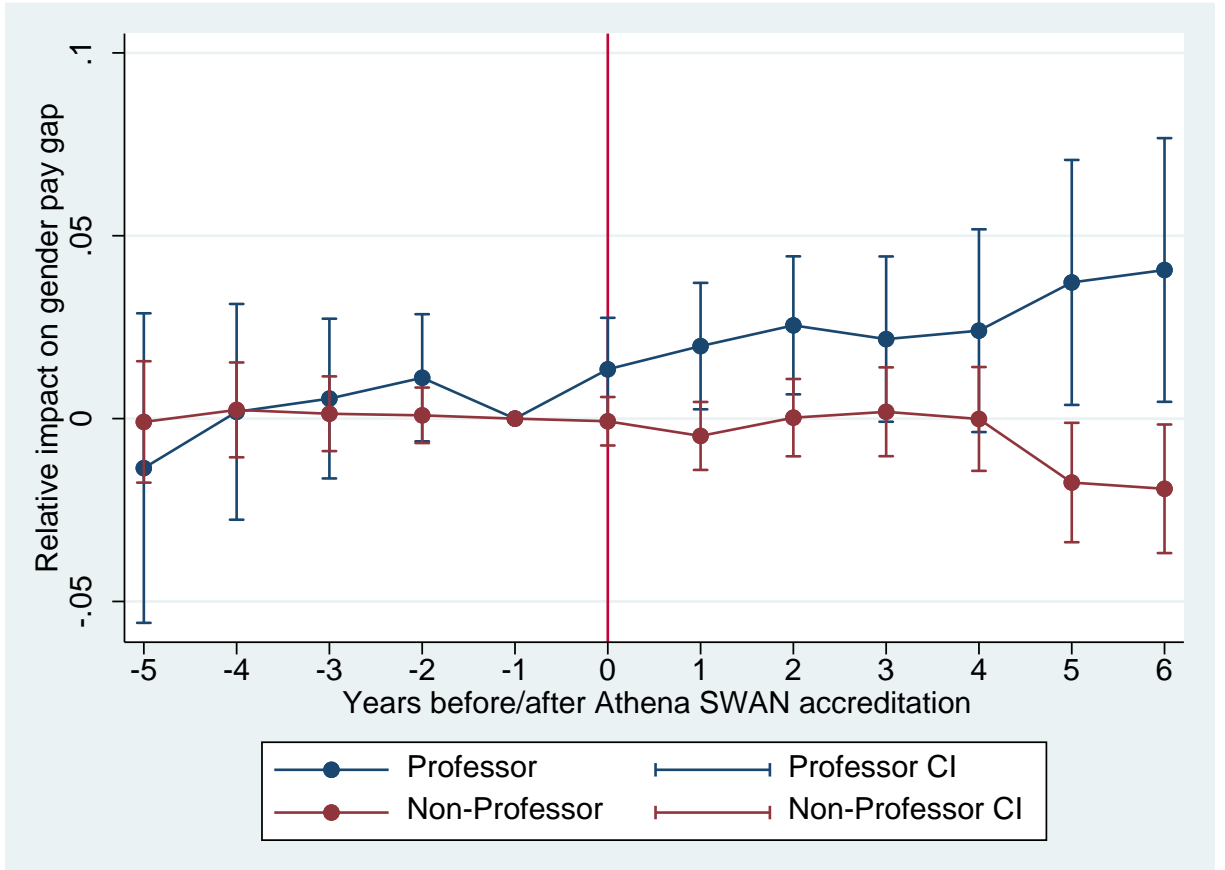

Notes: Source 2009-2016 HESA dataset. Sample: 155 STEM departments that have received have received Athena Status by 2016 and we can include in the event study analysis. The figure plots the estimated differential effect of Athena Swan accreditation on female pay relative to male pay. One year before Athena SWAN accreditation is used as the reference year. A positive coefficient indicates a narrowing in the gender pay gap. 


\section{Discussion}

Analysis of high-quality, administrative data reveals gender gaps in economics. Women are underrepresented, particularly at senior level, and are paid less than their male counterparts. The status of women in economics is not systematically worse than in other disciplines but it is similar to STEM subjects. Discussion around encouraging women in STEM has been high profile, including national, government-funded initiatives. To date, the status of women in economics has not received similar attention, despite the role of economists in national policy-making and the importance of diversity in the discipline.

Positive steps are required to improve the status of women in economics. This includes measures to attract more female students to study economics (not the focus of this paper) and measures to support women in economics. For the latter, the literature identifies mentoring and diversity plans as likely to be the most effective. The European Central Bank diversity plan, including explicit targets and a bundle of measures to support women, shows what can be done. Our evidence suggests that the UK Athena Swan initiative has helped to close the gender pay gap among senior academics; extending Athena Swan from STEM to other subjects is therefore a positive step although more needs to be done to close gender pay gaps at junior levels and to improve the representation of women in economics. The literature also highlights the importance of using objective assessment processes; academic promotion relies on both student evaluations and assessment letters which may be subject to bias.

Support for female academics is even more important in the current time. The closure of schools and nurseries to stop the spread of coronavirus has left women bearing the brunt of the additional childcare even when they are working (Sevilla and Smith, 2020). There are early indications that this is having a negative effect on the productivity of mid-career women - shown by a smaller share of research papers on COVD19 among leading working papers series (Amano-Pantino et al, 2020). Even if the disruption is relatively short-lived, it may have a long-lasting effects, causing gender gaps to widen further, unless those with caring responsibilities are given support. 


\section{References:}

Aghion, P., Dewatripont, M., Hoxby, C., Mas-Colell, A. and Sapir, A. (2010) 'The governance and performance of universities: evidence from Europe and the US', Economic Policy 25(61) pp. $7-$ 59

AEA (2019) AEA Professional Climate Survey: Main Findings https://www.aeaweb.org/resources/member-docs/climate-survey-results-mar-18-2019

Amano-Patino, N., Faraglia, E., Giannitsarou, C. and Z. Hasna (2020) "Who is doing new research in the time of COVID-19? Not the female economists" https://voxeu.org/article/who-doing-newresearch-time-covid-19-not-female-economists

Antecol, H., Bedard, K. and Stearns, J. (2018) 'Equal but inequitable: Who benefits from genderneutral tenure clock stopping policies?’, American Economic Review, 108(9), pp. 2420-2441.

Auriol, E., Friebel, G. and S. Wilhelm (2019) Women in European Economics https://womeneconomics.com/download/Auriol.Friebel.Wilhelm_2019_Women.in.Economics.pdf

Avilova, T. and C. Goldin (2018) 'What can UWE do for economics?' AEA papers and proceedings 108 pp. $186-90$

Babcock, L., Recalde, M., Vesterlund, L. and L. Weingart (2017) 'Gender Differences in Accepting and Receiving Requests for Tasks with Low promotability', American Economic Review, 107(3), pp. $714-47$

Bagues, M., Sylos-Labini, M. and Zinovyeva, N. (2017) 'Does the gender composition of scientific committees matter?’, American Economic Review, 107(4), pp. 1207-1238.

Bandiera, O., Rana, S. A. and Guo, X. (2016) The Gender and Ethnicity Earnings Gap at LSE.

Bayer, A. and Rouse, C. E. (2016) 'Diversity in the economics profession: A new attack on an old problem', Journal of Economic Perspectives, 30(4), pp. 221-242.

Behavioural Insights Team (2018) Reducing the gender pay gap and improving equlity in organisations https://www.bi.team/publications/reducing-the-gender-pay-gap-and-improvinggender-equality-in-organisations/

Bennedsen, M., Simintzi, E., Tsoutsoura, M. and D. Wolfenzon (2019) `Do firms respond to gender pay gap transparency?' NBER Working Papers 25435

Blackaby, D., Booth, A. L. and Frank, J. (2005) 'Outside offers and the gender pay gap: Empirical evidence from the UK academic labour market’, Economic Journal, 115(501), pp. F81-107

Blau, F. D., Currie, J. M., Croson, R. T. A. and Ginther, D. K. (2010) 'Can Mentoring Help Female Assistant Professors? Interim Results from a Randomized Trial', American Economic Review: Papers \& Proceedings, 100(May), pp. 348-352

Boring, A. (2017) 'Gender biases in student evaluations of teaching', Journal of Public Economics, 145, pp. $27-41$

Boring, A. and Arnaud, P. (2017) 'Reducing discrimination through norms or information: Evidence from a field experiment on student evaluations of teaching' IAST Working Papers 17-72, Institute for Advanced Study in Toulouse (IAST).

Bosquet, C., Combes, P. and Garcia-Penalosa () "Gender and Promotions: Evidence from Academic Economists in France"- Scandinavian Journal of Economics 121 (3) pp. 1020-1053

Buckles, K. (2019) 'Fixing the leaky pipeline: Strategies for making economics work for women at every stage’, Journal of Economic Perspectives, 33(1), pp. 43-60.

Card, D., DellaVigna, S., Funk, P. and Iriberri, N. (2019) Are Referees and Editors in Economics 
Gender Neutral?, NBER Working Paper Series 25967.

Carrell, S. E., Page, M. E. and West, J. E. (2010) 'Sex and science: How professor gender perpetuates the gender gap’, Quarterly Journal of Economics, 125(3), pp. 1101-1144.

Ceci, S.J., Ginther, D.K., Kahn, S. and Williams, W. . (2014) 'Women in Academic Science: A Changing Landscape Stephen’, Psychological Science in the Public Interest, 15(3), pp. 75-141.

Chari, A. and P. Goldsmith-Pinkham (2017) 'Gender Representation in Economics Across Topics and Time: Evidence from the NBER Summer Institute', NBER Working Papers. https://www.nber.org/papers/w23953.pdf

Corsi, M., Ippoliti, C. D. and Zacchia, G. (2014) 'Gendered careers: women economists in Italy'. Working Paper CEB 17

Crawford, C., Shepard, N. and S. Smith (2018) Why do so few women study economics? https://www.res.org.uk/resources-page/why-do-so-few-women-study-economics--2018-pdf.html

CSWEP (2015) CSWEP 2015 Statistical Report on the Status of Women in the Economics Profession. Available at: https://www.aeaweb.org/about-aea/committees/cswep/survey/2015-statisticalreport.

CSWEP (2017) Report from the American Economic Association's Committee on the Status ofWomen in the Economics Profession.

CWEN (2015) CWEN/RFE Report on the Satus of Women in Canadian Economics. Available at: http://www.cwen-rfe.org/wp-content/uploads/2015/09/CWENRFE-report-2015.pdf;

Ductor, L, S Goyal and A Prummer (2018), “Gender and collaboration”, Cambridge-INET Working PaperNo. 1807.

Dupas, P., Modestino, A., Niederle, M. and Wolfers, J. (2020) Gender and the Dynamics of Economics Seminars, mimeo

Dutt, K., Pfaff, D., Bernstein, A. et al. Gender differences in recommendation letters for postdoctoral fellowships in geoscience. Nature Geosci 9, 805-808 (2016). https://doi.org/10.1038/ngeo2819

De Fraja, G., Facchini, G. and Gathergood, J. (2019) “Academic salaries and public evaluation of university research: Evidence from the UK Research Excellence Framework". Economic Policy Volume 34, Issue 99, July 2019, Pages 523-583

Epifanio and V. Troeger (2019) "Bargaining over maternity pay: Evidence from UK universities", Journal of Public Policy

Gamage, D. K. and Sevilla, A. (2019) 'Gender Equality and Positive Action: Evidence from UK Universities’, AEA Papers and Proceedings, 109, pp. 105-109.

Ginther, D.K. and Kahn, S. (2009) 'Does science promote women? Evidence from academia 19732001', in In Science and engineering careers in the United States: An analysis of markets and employment, pp. 163-194.

Ginther, D. K. and Hayes, K. J. (2003) 'Gender differences in salary and promotion for faculty in the humanities’, Journal of Human Resources, 38(1), pp. 34-73.

Ginther, D. K. and Kahn, S. (2004) 'Women in economics: Moving up or falling off the academic career ladder?’, Journal of Economic Perspectives, 18(3), pp. 193-214.

Ginther, D. K. and Kahn, S. (2014) 'Women’s careers in academic social science: progress, pitfalls, and plateaus', The economics of economists, pp. 285-315.

Ginther, D., Currie, J., Blau, F. and R. Croson (2020 "Can Mentoring Help Female Assistant Professors in Economics? An Evaluation by Randomized Trial" NBER Working Paper No. 
Guarino, C. and V. Borden (2018) Faculty Service Loads and Gender: Are Women Taking Care of the Academic Family? Research in Higher Education 58, pp 672-694

Gregory-Smith, I. (2018) 'Positive Action Towards Gender Equality: Evidence from the Athena SWAN Charter in UK Medical Schools’, British Journal of Industrial Relations, 56(3), pp. 463483.

Heckman, J. and Moktan, S. (2019) 'Publishing and Promotion in Economics: The Tyranny of the Top Five', NBER Working Paper.

Hengel, E. (2017) 'Publishing while Female: Are Women Held to Higher Standards? Evidence from Peer Review’, Cambridge Working Paper Economics.

HESA (2017) HESA staff record 2012/13-2015/16, Higher Education Statistics Agency Limited, Chichester

Hospido, L. and Sanz, C. (2019) 'Gender Gaps in the Evaluation of Research: Evidence from Submissions to Economics Conferences’,

Hospido, Laura and Laeven, Luc A. and Lamo, Ana, The Gender Promotion Gap: Evidence from Central Banking (April 16, 2019). Banco de Espana Working Paper No. 1915. Available at SSRN: https://ssrn.com/abstract=3373009 or http://dx.doi.org/10.2139/ssrn.3373009

House of Commons (2016) Increasing Diversity in STEM careers file://C:/Users/ecsls/Downloads/CDP-2016-0014.pdf

Langan, Andrew. “(Job Market Paper) Female Managers and Gender Disparities: The Case of Academic Department Chairs”. (Working Papers). Print

Lundberg, S. and Stearns, J. (2019) 'Women in economics: Stalled progress', Journal of Economic Perspectives, 33(1), pp. 3-22

MacNell, L., Driscoll, A. and A. Hunt (2015) "What's in a Name: Exposing Gender Bias in Student Ratings of Teaching.” Innovative Higher Education 40(4): 291-303

Madera, J., Hebl, M., and R. Martin (2009). Gender and letters of recommendation for academia: Agentic and communal differences. Journal of Applied Psychology, 94(6), pp. 15911599. https://doi.org/10.1037/a0016539

Madera, J., Hebl, M., Dial, H., Martin, R. and V. Valian (2019).Raising Doubt in Letters of Recommendation for Academia: Gender Differences and Their Impact. Journal of Business and Psychology, 34 pp. 287 - 303

May, A., McGarvey, M. and R. Whaples (2014) “Are Disagreements among Male and Female Economists Marginal at Best?: A Survey of AEA Members and Their Views on Economics.” Contemporary Economic Policy 32 (1): 111-32

May, A., McGarvey, M. and D. Kucera (2018 "Gender and European Economic Policy: A survey of the views of European Economists on Contemporary Economic Policy" Kyklos 71 (1): 162-83.

McCormack, J., Propper, C. and Smith, S. (2014) 'Herding cats? Management and university performance’, Economic Journal, 124(578), pp. 534-564.

Moss-Rascusin, C., Dovidio, J., Brescoll, M. and J. Handelsman (2012) "Science faculty’s subtle gender biases favor male students" PNAS 109 (41) 16474-16479

Mumford, K. (1997) The Gender Balance of Academic Economists in the UK'. Royal Economic Society Women's Committee Report.

Mumford, K. and Sechel, C. (2019) 'Pay and Job Rank among Academic Economists in the UK: Is 
Gender Relevant', British Journal of Industrial Relations, pp. 1-32.

Sarsons, H. (2017) Recognition for group work: Gender differences in academia, AEA papers and proceedings

Sarsons, H. and G. Xu (2015) "Confidence Men? Gender and Confidence: Evidence among Top Economists" mimeo

Schmader, Toni, Jessica Whitehead, and Vicki H. Wysocki. 2007. "A Linguistic Comparison of Letters of Recommendation for Male and Female Chemistry and Biochemistry Job Applicants." Sex Roles 57(7-8): 509-14.

Tao, Y. (2018) 'Earnings of Academic Scientists and Engineers: Intersectionality of Gender and Race/Ethnicity Effects', American Behavioral Scientist, 62(5), pp. 625-644.

Tenreyro, S. (2017) 'Royal Economic Society’s Report on The Gender Balance in UK Economics Departments and Research Institutes in 2016'.

Tomkins, A., Zhang, M. and Heavlin, W. D. (2017) 'Reviewer bias in single- versus double-blind peer review', Proceedings of the National Academy of Sciences of the United States of America, 114(48), pp. 12708-12713.

Ward, M. (2001) 'The gender salary gap in British academia’, Applied Economics, 33(13), pp. 16691681.

Wu, A (2018) "Gendered Language on the Economics J ob Market Rumors

Forum." AEA Papers and Proceedings, 108: 175-79. 


\section{Appendix A}

This section explains how we map the information in HESA to arrive to the academic discipline classification that we use in this paper. We classify disciplines into 4 broad categories: Economics, STEM, Social Science and Business management (classification I). We use the information about cost centres in the HESA dataset. Cost centres are defined as clusters within the university used by the university finance departments to allocate budgets. Table A1 shows how cost centres are matched to these four disciplinary broad subject categories. Economics and Business management are a cost centre of its own, STEM combines Chemistry and Engineering, Maths/Physics/Computer Science and Biology/Earth Sciences cost centres. Social science combines Politics and International Studies, Sociology and Social work \& social policy cost centres. We also use a more disaggregated classification (as shown in column 2 of Table A1) in table 1 in order to compare our results to the US. This mapping methodology assigns the discipline of Business Management to economics schools that are within the business and management department. This is the case of Imperial College, the University of Leeds, and Queen's University of Belfast. Tables A2 provides the cost centres in broad subject categories in the 24 Russell group universities. Some cost centres are not observed over the full period. 
Table A1: List of cost centre included the analysis and their classification.

Cost Centres in HESA

Earth, marine \&

environmental sciences

Biosciences

Chemistry

General engineering

Chemical engineering

Mineral, metallurgy \&

materials engineering

Civil engineering

Electrical, electronic \&

computer engineering

Mechanical, aero \&

production engineering

Physics

IT, systems sciences \&

computer software

engineering

Mathematics

Politics \& international studies

Sociology

Social work \& social policy

Business \& management studies

Economics \& econometrics

Discipline classification in:

(1)

(2)

Classification I

STEM

STEM

STEM

STEM

STEM

STEM

STEM

STEM

STEM

STEM

STEM

STEM

Social Science

Social Science

Social Science
Classification II (for Table 1)

Biology/Earth Sciences

Biology/Earth Sciences

Chemistry and Engineering

Chemistry and Engineering

Chemistry and Engineering

Chemistry and Engineering

Chemistry and Engineering

Chemistry and Engineering

Chemistry and Engineering

Maths/Physics/Computer Science

Maths/Physics/Computer Science

Maths/Physics/Computer Science

Politics and International Studies

Sociology

Not included

Business \& Management

Economics

Economics

Note: The table list the mapping of department/cost centre listed in HESA to their respective subject classifications used in the analysis. 
Table A2: Universities and Cost centres (2013-2016)

\begin{tabular}{|c|c|c|c|c|}
\hline University & Economics & STEM & Social Science & B\&M \\
\hline \multirow{11}{*}{$\begin{array}{l}\text { University of } \\
\text { Birmingham }\end{array}$} & \multirow[b]{11}{*}{ Economics } & Mineral, metallurgy \& materials engineering & \multirow{8}{*}{$\begin{array}{l}\text { Social work \& } \\
\text { social policy }\end{array}$} & \multirow{11}{*}{$\begin{array}{l}\text { Business \& } \\
\text { management } \\
\text { studies }\end{array}$} \\
\hline & & Civil engineering & & \\
\hline & & Biosciences & & \\
\hline & & Electrical, electronic \& computer engineering & & \\
\hline & & Mechanical, aero \& production engineering & & \\
\hline & & IT, systems sciences \& computer software & & \\
\hline & & engineering & & \\
\hline & & Chemistry & & \\
\hline & & Mathematics & Politics \& & \\
\hline & & Chemical engineering & international & \\
\hline & & Physics & studies & \\
\hline & & Civil engineering & & \\
\hline & & IT, systems sciences \& computer software & & \\
\hline & & engineering & & \\
\hline & & Electrical, electronic \& computer engineering & Sociology & \\
\hline & & Chemistry & Social work \& & \\
\hline & & Biosciences & social policy & \\
\hline & & Mechanical, aero \& production engineering & Politics \& & Business \& \\
\hline University of & & Physics & international & management \\
\hline Bristol & Economics & Mathematics & studies & studies \\
\hline
\end{tabular}

IT, systems sciences \& computer software

engineering

Physics

Mathematics

Mineral, metallurgy \& materials engineering

Biosciences

Chemical engineering

Politics \&

General engineering

international Business \&

Chemistry

studies

management

Cambridge

Economics

Electrical, electronic \& computer engineering studies 


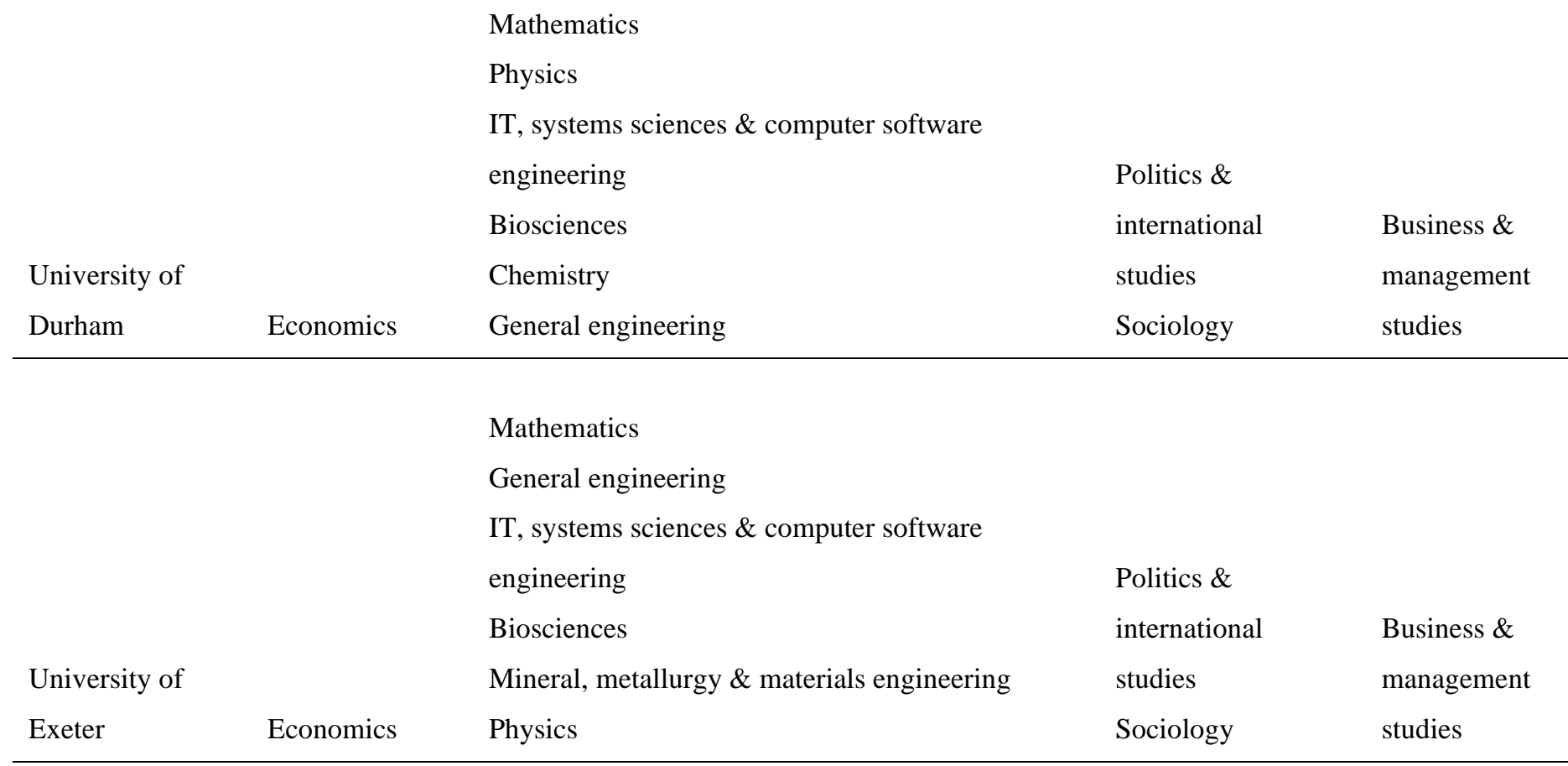

\section{Chemistry}

Mineral, metallurgy \& materials engineering

Mathematics

Electrical, electronic \& computer engineering

IT, systems sciences \& computer software

engineering

Civil engineering

Social work \&

Biosciences

social policy

Physics

Politics \&

Business \&

University of

Chemical engineering

international

management

Leeds

Mechanical, aero \& production engineering

studies

studies

Mathematics

Civil engineering

Biosciences

Mineral, metallurgy \& materials engineering

Mechanical, aero \& production engineering

Physics

Chemistry

IT, systems sciences \& computer software

University of engineering

Politics \&

international

Business \&

studies

management

Liverpool

Economics

Electrical, electronic \& computer engineering

studies 


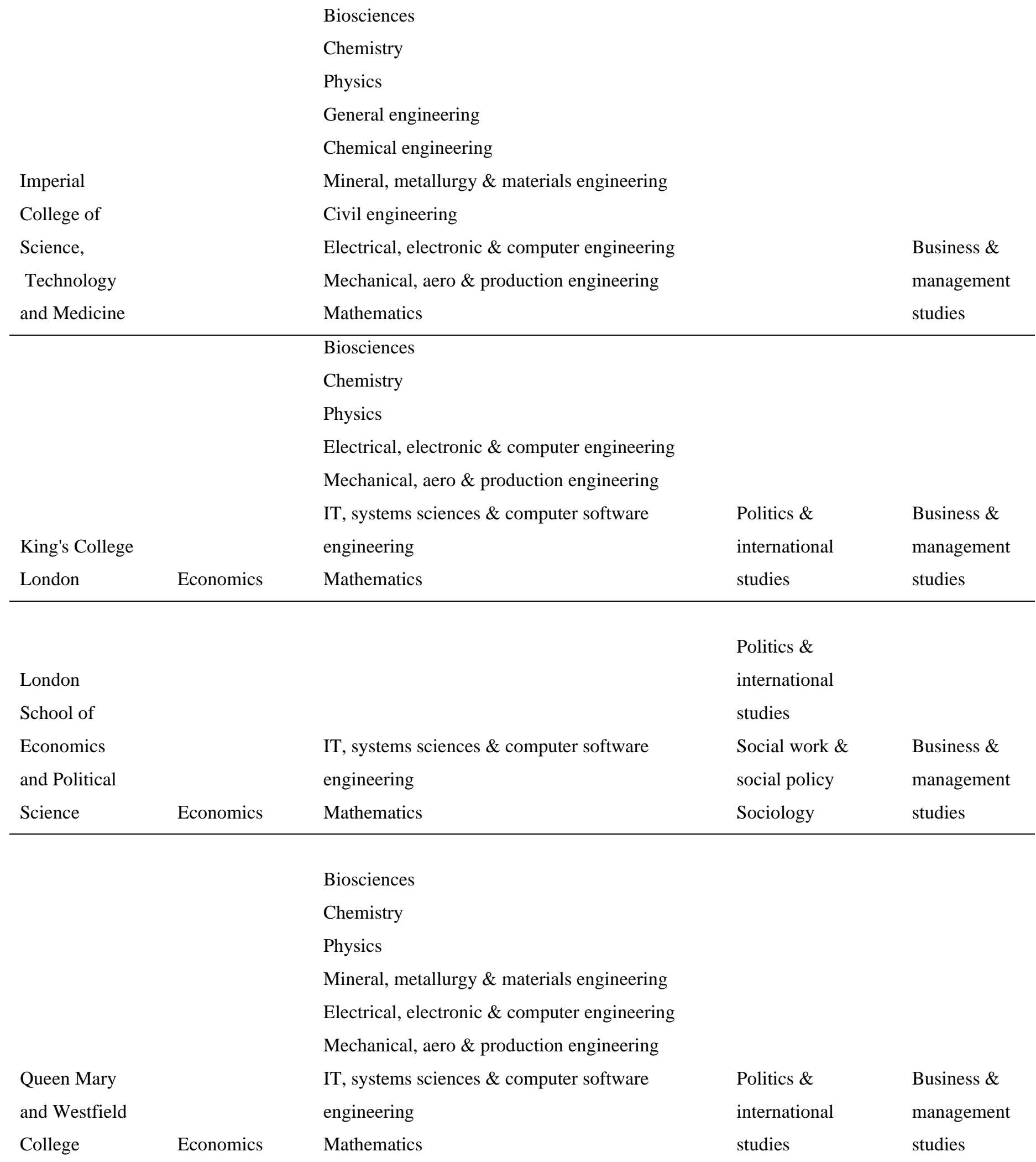




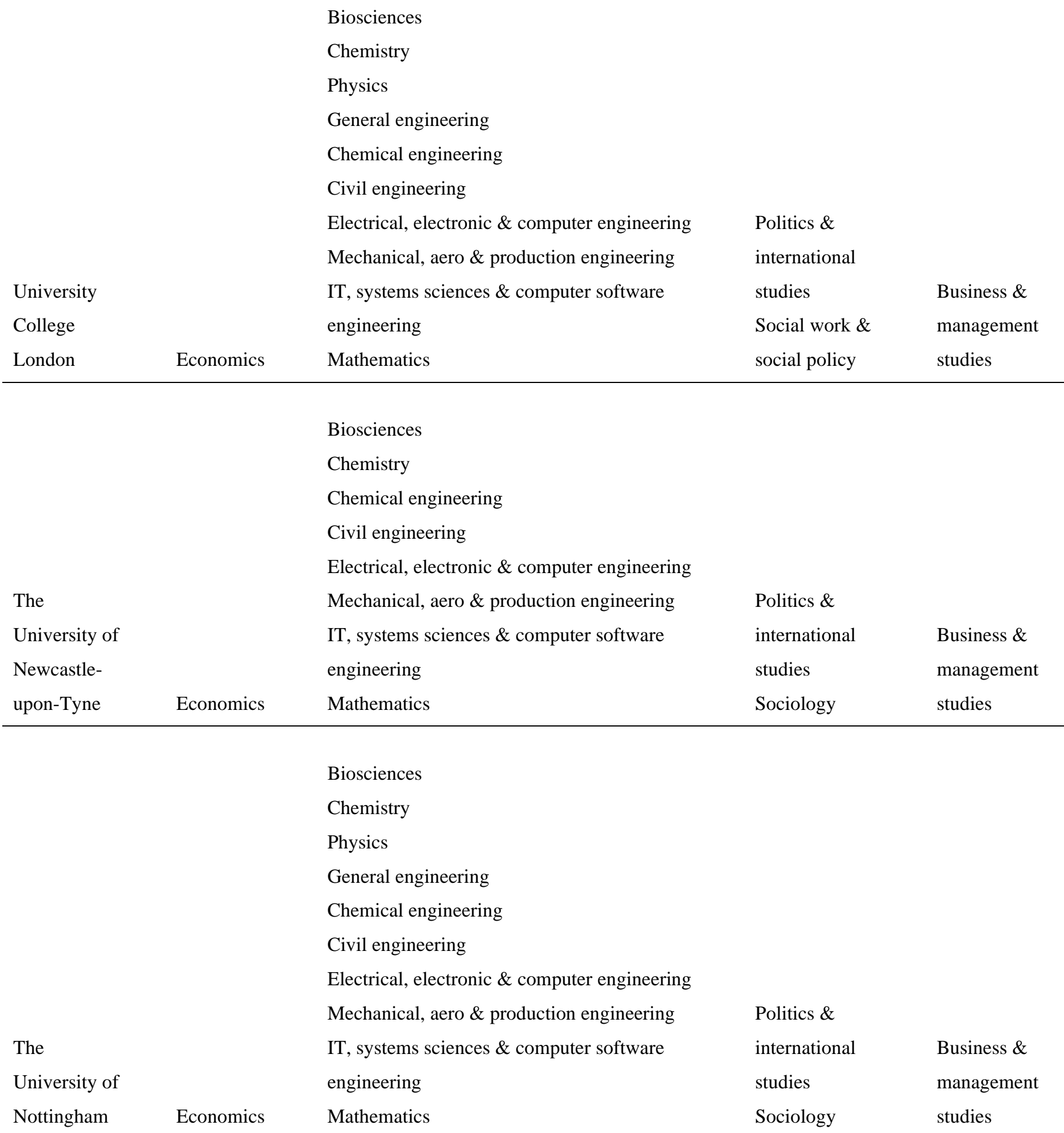


Biosciences

Chemistry

Physics

Politics \&

General engineering

international

Mineral, metallurgy \& materials engineering

studies

The

University of

Oxford
IT, systems sciences \& computer software

engineering

Mathematics
Social work \&

Business \&

social policy

management

Sociology

\section{Biosciences}

Chemistry

Physics

Chemical engineering

Mineral, metallurgy \& materials engineering

Civil engineering

Electrical, electronic \& computer engineering

Mechanical, aero \& production engineering

Politics \&

The

IT, systems sciences \& computer software

international

Business \&

University of engineering

studies

management

Sheffield

Economics

Mathematics

Sociology

studies

\section{Biosciences}

Chemistry

Physics

Civil engineering

Electrical, electronic \& computer engineering

Politics \&

Mechanical, aero \& production engineering

international

The

IT, systems sciences \& computer software

studies

Business \&

University of engineering

Social work \&

management

Southampton

Economics

Mathematics

social policy

studies

\section{Biosciences}

Chemistry

Physics

General engineering

The

University of

Warwick
IT, systems sciences \& computer software

engineering

Mathematics
Politics \&

international

studies

Social work \& $\quad$ Business \&

social policy

management

Sociology studies 


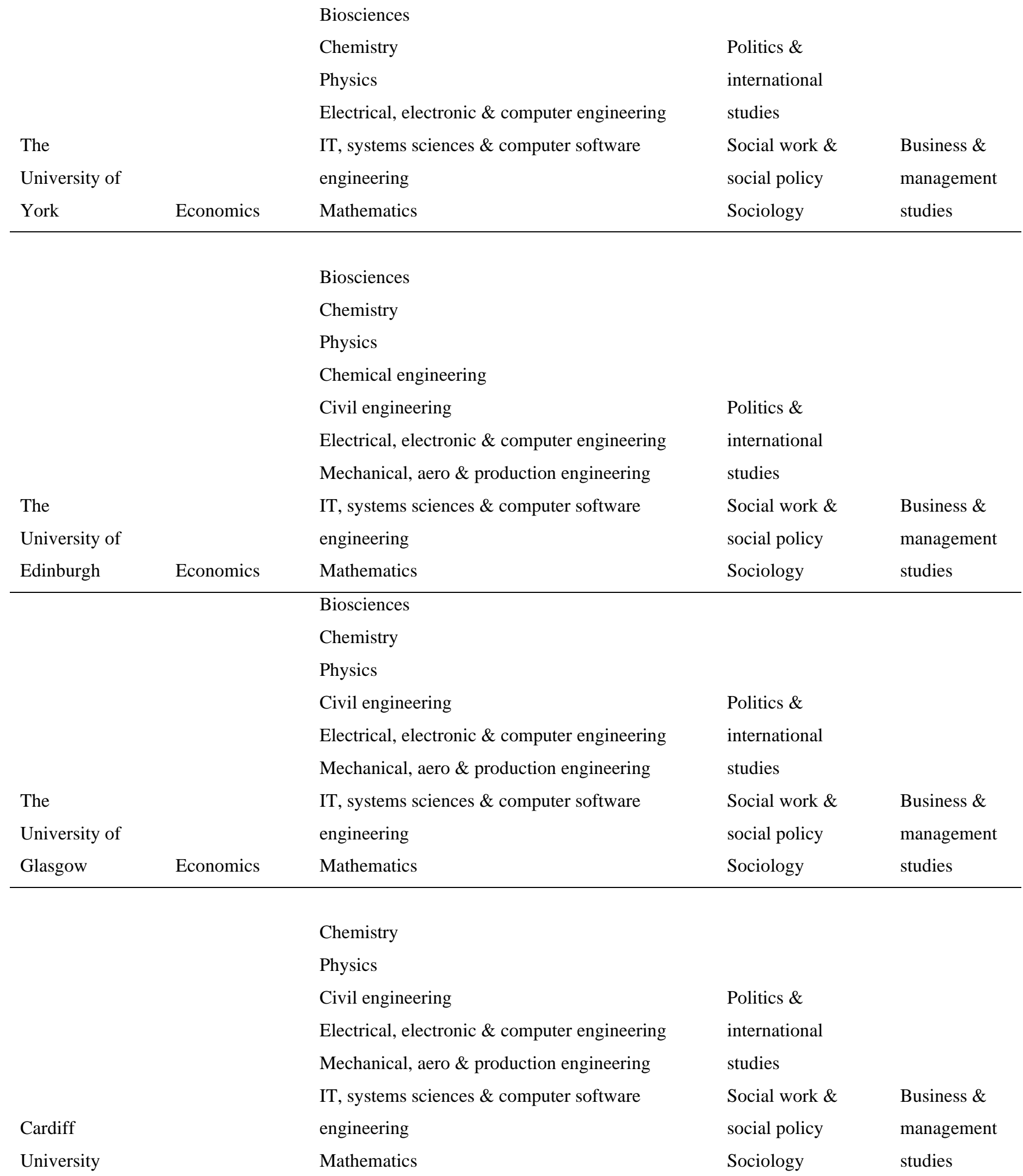




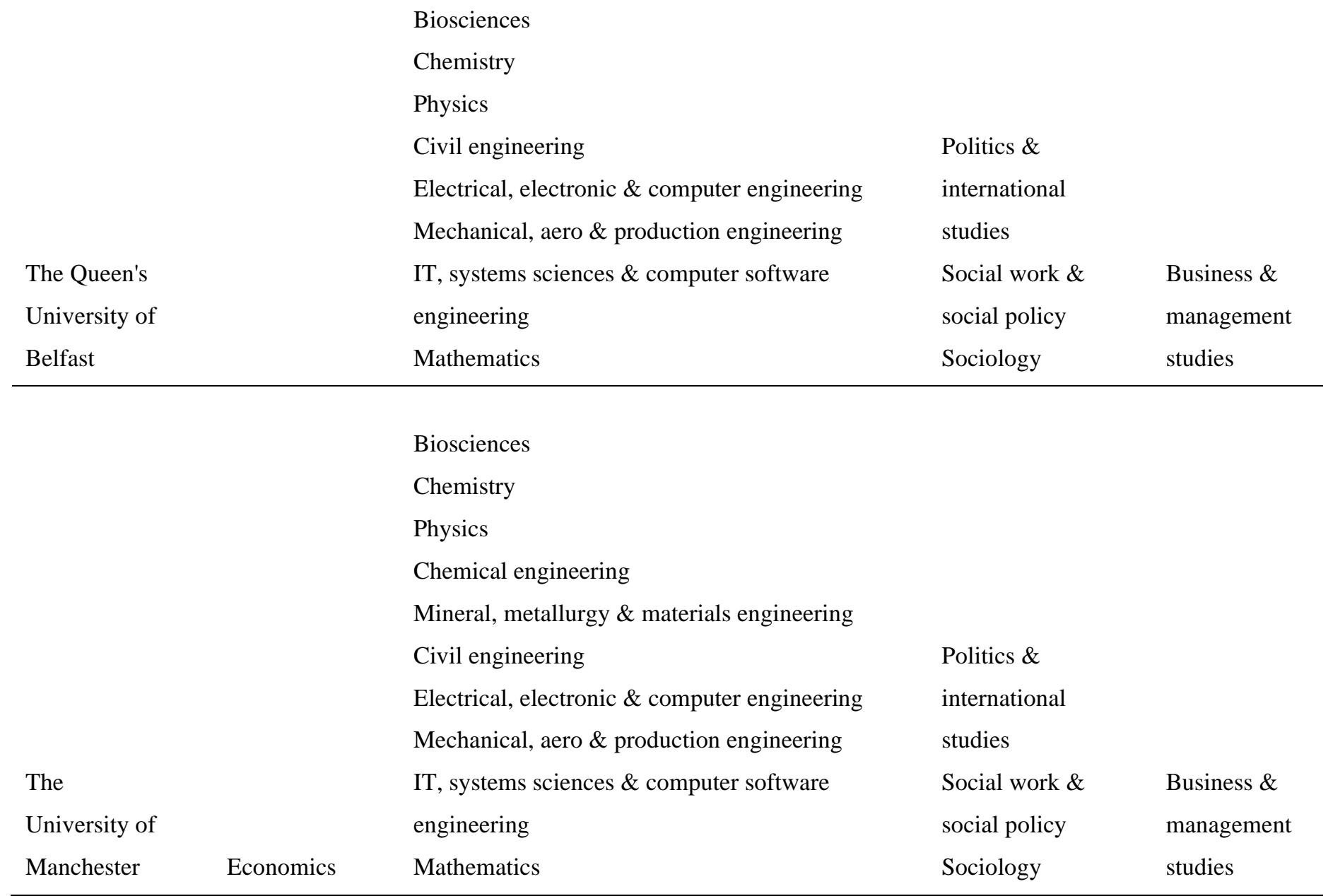

Notes: Source HESA 2013-2016 dataset. BM Refers to Business and Management. At University of Durham, IT, systems sciences \& computer software engineering and Economics cost centres are observed for 2 years. Business and management cost centre is observed for 3 years. At University of Liverpool, Mineral, metallurgy \& materials engineering cost centre is observed for 1 year; Civil engineering cost centres is observed for 3 years. At Kings College, Sociology cost centre is observed for 1 year. At LSE, IT, systems sciences \& computer software engineering cost centre is observed for 3 years. At University of Nottingham, Earth, marine \& environmental sciences cost centre is observed for 1 year, Social work \& social policy cost centre is observed for 3 years. At University of Sheffield: IT, systems sciences \& computer software engineering cost centre is observed for 3 years; Social work \& social policy cost centre is observed for 2 years. At Cardiff University Economics cost centre is for observed for 3 years. All other cost centre are observed for the full period (2013-2016) 
Table A3: Description of the variables

\begin{tabular}{ll}
\hline \multicolumn{1}{c}{ Variable } & \multicolumn{1}{c}{ Description } \\
\hline Female Representation & The Variable takes value 1 if the individual is a female and \\
& zero otherwise. The variable is constructed using the \\
& gender variable recorded in the HESA dataset \\
The variable takes value 1 in year $t$ and year t+s, s>0, if \\
the individual becomes a professor in year t and zero \\
otherwise. The variable is constructed using the academic \\
rank variable that records all academic ranks including \\
professorial rank. \\
The variable takes value 1 if the individual is employed in \\
part-time basis and 0 otherwise. The variable is constructed \\
using the terms on employment variable recorded in HESA \\
that indicates whether the individual is employment on \\
part-time, full-time or atypical basis. \\
The variable takes value 1 if the individual is a female and \\
is also appointed as the head of school in year $t$ in \\
department $d$. The variable is constructed using the gender \\
and academic rank variable. HESA records head of school \\
as a separate rank. \\
Age is recorded in the HESA dataset \\
The variable records the number of years since joining the \\
current university of employment. The variable is \\
constructed by taking the difference between the year t and \\
year of joining the university. \\
This variable records the real log full-time equivalent pay \\
for the main job recorded in HESA dataset. CPI 2016 \\
adjustment is applied to the nominal full time equivalent \\
pay recorded in HESA and logs are applied. ${ }^{13}$ \\
The REF 2014 Grade point average (GPA) is merged with \\
HESA dataset using the REF unit of assessment at \\
university level. ${ }^{14}$ HESA records the REF unit of \\
assessment for individuals that are submitted to the REF \\
Tenure \\
matched to individuals who have submitted to that \\
marticular assessment unit in the university. The matched \\
REF GPA reflect the university level score for a given \\
assessment unit and not at departmental level.
\end{tabular}

\footnotetext{
${ }^{13}$ Refer: https://www.ons.gov.uk/economy/inflationandpriceindices

14 "It is calculated by multiplying the percentage of research in each grade by its rating, adding them all together and dividing by 100”- Refer https://ref2014.leeds.ac.uk/brand-new-page/definitions/
} 


\section{Appendix B}

\section{Athena SWAN Data construction.}

We use the award booklets published by the Equality Challenge Unit (ECU) to construct an accreditation history for the cost centres in our sample since $2011 .{ }^{15}$ Booklets are published from 2011 onwards for every round of accreditation, and contain a department/school name, the type of award (bronze, silver and gold), and the month and year of award. There is also a list of universities that received Athena SWAN accreditation during that year, and when these universities first signed the charter. The booklets also feature additional information about the accreditation process such as content submitted by winners and good practice examples highlighted by accreditation panels.

Our Athena variable takes value 1 for individual $i$ in year $t$ if the cost centre $j$ holds an Athena Swan accreditation in year $t$. For individuals in cost centres getting a first-time accreditation during our sample period there is no issue computing the Athena Swan accreditation variable. The Athena Swan accreditation variable takes value 1 for all the years in our sample for individuals in cost centres that get the Athena Swan accreditation renewed during this period. This is because the Athena Swan accreditation lasts for 3 years before it can either be renewed or withdrawn. Given that we have 4 years of data, any cost centre renewing its accreditation during this period would have been accredited during the whole of the period in our sample. For individuals in cost centres that do not get accreditation or renewed during the sample period 2013-2016, we check the 2011 and 2012 booklets and assign a value of 1 in the three years following the accreditation or renewals.

Our sample consists of 24 RG universities with at most 11 HESA cost centres in STEM subjects. ${ }^{16}$ We have 182 cost centres in any given year over our sample period. ${ }^{17}$ We do not have information on

\footnotetext{
${ }^{15}$ The booklets can be found at the webpage: https://www.ecu.ac.uk/equality-charters/athena-swan/athenaswan-members/

${ }^{16} 11$ cost centres include: Biosciences, Chemistry, Chemical Engineer, Civil Engineer, Electrical Electronic and Computer Engineer, General Engineer, IT System Sciences and Computer Software Engineer, Mechanical Aero and Production Engineer, Mathematics, Mineral Metalogy and Material Engineer, Physics.

17 There are 198 cost centres in the dataset in the 24 Russell group universities. Of the 192, 182 departments are observed over the full time period - 2009-2016. The departments that are not fully observed are: University of Cambridge- Electrical, electronic \& computer engineering and IT, systems sciences \& computer software engineering; University of Durham - IT, systems sciences \& computer software engineering; University of Leeds- General engineering; University of Liverpool - Mineral, metallurgy \& materials engineering and Civil engineering; King's College London - Chemistry and Mechanical, aero \& production engineering; London School of Economics and Political Science- IT, systems sciences \& computer software engineering; University College London- General engineering; University of Newcastle- Physics; University of Sheffield- IT, systems sciences \& computer software engineering; University of Southampton- General engineering; University of Edinburgh- General engineering; University of Nottingham- General Engineering and Mineral, metallurgy \& materials engineering
} 
departments/schools in our HESA sample, instead we have cost centre information. Each cost centre can be made up of several departments/schools, and also a department/school can comprise several cost centres. From the booklets, there are 155 departments/schools which were accredited during this period (40 up to 2012, 56 in 2013, 46 in 2014, 43 in 2015, and 47 in 2016). In the first round of our matching procedure, we assign a department (in the Athena SWAN accreditation data) to one or multiple cost centres in our HESA sample. This is the case with engineering departments in Athena SWAN. For example, if an engineering school obtains accreditation in a given university, this accreditation will show as multiple cost centres (all engineer cost centres) in our HESA sample. The second round in our matching method first assigns a given school or department (in the Athena SWAN accreditation data) to a single cost centre in our HESA sample. For example, Department of Physics and Department of Physics- The Cavendish Laboratory at Cambridge University are identified as two different departments in the Athena SWAN accreditation data, with accreditation awarded in November 2013 and April 2013 respectively, and both are matched to one cost centre in 2013 (the physics cost centre in Cambridge University) in our HESA sample.

Column 1 in Table B1 shows the number of departments/schools that obtained or renewed accreditation in each year of our sample. Column 2 shows the cost centre equivalent in our HESA sample after the first round of our matching procedure, and Column 3 shows the cost centre equivalent in our HESA sample after the second round of our matching procedure. For example, Column 1 in Table B1 shows that in 2014 there were 45 departments who either got accredited or renewed its accreditation, equivalent to 57 cost centres (Column 3) out of 182 cost centres in the sample. See Tables B.2 and B.3 for a detailed description. 
Table B1: HESA and Athena Match

(1)

(2)

(3)

(4)

(5)

Athena

HESA (Cost Cumulative centres

\begin{tabular}{|c|c|c|c|c|c|}
\hline & $\begin{array}{c}\text { Athena } \\
\text { (Department } \\
\text { accreditation) }\end{array}$ & $\begin{array}{l}\text { cost } \\
\text { centre } \\
\text { match }\end{array}$ & $\begin{array}{l}\text { HESA (Cost } \\
\text { centre } \\
\text { accreditation) }\end{array}$ & $\begin{array}{c}\text { Cumulative } \\
\text { number } \\
\text { Accreditation }\end{array}$ & $\begin{array}{c}\text { centres } \\
\text { accredited }\end{array}$ \\
\hline 2011 & 9 & 12 & 12 & 44 & $24.18 \%$ \\
\hline 2012 & 29 & 31 & 30 & 75 & $41.21 \%$ \\
\hline 2013 & 52 & 62 & 59 & 109 & $59.89 \%$ \\
\hline 2014 & 45 & 57 & 53 & 137 & $75.27 \%$ \\
\hline 2015 & 44 & 51 & 43 & 148 & $81.32 \%$ \\
\hline 2016 & 42 & 49 & 47 & 155 & $85.16 \%$ \\
\hline
\end{tabular}


Table B.2: Round 1 of Matching Procedure

\begin{tabular}{|c|c|c|c|}
\hline Year & University & Athena Swan Department/School & HESA Cost Centre \\
\hline 2011 & University of Nottingham & Faculty of engineering & $\begin{array}{l}\text { Civil Engineering, } \\
\text { Chemical Engineering, } \\
\text { Electrical, Electronic \& Computer Engineering } \\
\text { Mechanical, Aero \& Production Engineering, }\end{array}$ \\
\hline 2012 & Cardiff University & School of engineering & $\begin{array}{l}\text { Civil engineering, } \\
\text { Electrical, electronic \& computer engineering, } \\
\text { Mechanical, aero \& production engineering }\end{array}$ \\
\hline \multirow[t]{3}{*}{2013} & University of Southampton & $\begin{array}{l}\text { Faculty of Engineering and } \\
\text { environment }\end{array}$ & $\begin{array}{l}\text { Civil Engineering, } \\
\text { Electrical, electronic \& computer engineering } \\
\text { Mechanical, Aero \& Production Engineering, }\end{array}$ \\
\hline & University of Leeds & faculty of engineering & $\begin{array}{l}\text { Chemical Engineering, } \\
\text { Mineral, Metallurgy \& Materials Engineering, } \\
\text { Civil Engineering, } \\
\text { Electrical, Electronic \& Computer Engineering, } \\
\text { Mechanical, Aero \& Production Engineering, } \\
\text { IT, Systems Sciences \& Computer Software } \\
\text { Engineering }\end{array}$ \\
\hline & The University of Edinburgh & School of Engineering & $\begin{array}{l}\text { Chemical Engineering } \\
\text { Civil Engineering. } \\
\text { Electrical, Electronic \& Computer Engineering, } \\
\text { Mechanical, Aero \& Production Engineering. }\end{array}$ \\
\hline 2014 & University of Bristol & Queens School of Engineering & $\begin{array}{l}\text { Civil Engineering, } \\
\text { Electrical, Electronic \& Computer Engineering, } \\
\text { Mechanical, Aero \& Production Engineering, } \\
\text { IT, Systems Sciences \& Computer Software } \\
\text { Engineering }\end{array}$ \\
\hline
\end{tabular}


University of Liverpool

University of Nottingham

King's College London
School of Engineering

Faculty of engineering Sciences
Mechanical, Aero \& Production Engineering, IT, Systems Sciences \& Computer Software Engineering

Civil Engineering,

Chemical Engineering,

Electrical, Electronic \& Computer Engineering Mechanical, Aero \& Production Engineering,

Chemistry,

Mathematics,

Physics,

Engineering, Electrical, electronic \& computer engineering,

Mechanical, aero \& production engineering, IT, systems sciences \& computer software

Chemical Engineering,

Mineral, Metallurgy \& Materials Engineering, Civil Engineering,

Electrical, Electronic \& Computer Engineering, Mechanical, Aero \& Production Engineering,

IT, Systems Sciences \& Computer Software Engineering

Civil Engineering,

Electrical, Electronic \& Computer Engineering, Mechanical, Aero \& Production Engineering

Civil Engineering,

Electrical, Electronic \& Computer Engineering, Mechanical, Aero \& Production Engineering, 
The University of Edinburgh

The University of Glasgow
School of Engineering

School of Engineering
Chemical Engineering;

Civil Engineering,

Electrical, Electronic \& Computer Engineering,

Mechanical, Aero \& Production Engineering

Civil Engineering

Electrical, Electronic \& Computer Engineering,

Mechanical, Aero \& Production Engineering 


\section{Round 2 of Matching Procedure}

In order to match the Athena SWAN dataset with the HESA, all accreditations that took place before 2013 have been treated as 2013. This facilitates us to merge departmental accreditations that occurred prior to the HESA period. To distinguish these records, a variable has been created to note the earliest year of accreditation. Aggregation of accreditations before 2013 creates multiple accreditations per cost centre that year if departments in the same cost centre have been accredited in 2011 and 2012. There are only three such cases: Imperial College London: Department of Chemistry upgraded to gold in 2013 from silver in 2011; Imperial College London, Department of Earth Science and Engineering (belonging to Mineral Metallurgy and Material Engineering) received accreditation in 2012 and Department of Materials (belonging to Mineral Metalogy and Material Engineering) received accreditation in 2013; UCL Department of Medical Physics and Bioengineering (belonging to bioscience cost centre) was accredited in 2012 and MRC Laboratory for Molecular Cell Biology (belonging to bioscience cost centre) received accreditation in 2012. To make the matching possible, we merge these multiple entries into one entry per cost centre. We conduct a similar exercise for the rest of the years, where we merge multiple departments to one cost centre. 
Table B.3: Round 2 of Matching Procedure

\begin{tabular}{|c|c|c|c|}
\hline Year & University & Athena Swan Department/School & HESA Cost Centre \\
\hline 2012 & UCL & $\begin{array}{l}\text { Department of Medical Physics and Bioengineering \& } \\
\text { MRC Laboratory for Molecular Cell Biology }\end{array}$ & Bioscience \\
\hline \multirow[t]{3}{*}{2013} & University of Cambridge & $\begin{array}{l}\text { Department of Physics \& Department of Physics- } \\
\text { The Cavendish Laboratory }\end{array}$ & Physics \\
\hline & University of Sheffield & $\begin{array}{l}\text { Department of Biomedical Science \& Department of Molecular } \\
\text { Biology and Biotechnology }\end{array}$ & Bioscience \\
\hline & University of Warwick & Department of Mathematics \& Department of Statistics & mathematics \\
\hline \multirow[t]{3}{*}{2014} & University of Bristol & School of Biochemistry \& School of Biological Sciences & Bioscience \\
\hline & University of Cambridge & Department of Genetics \& Department of Biochemistry & Bioscience \\
\hline & Newcastle University & $\begin{array}{l}\text { School of Biology, .Institute of Neuroscience \& Institute for Cell \& } \\
\text { Molecular Biosciences }\end{array}$ & Bioscience \\
\hline \multirow[t]{5}{*}{2015} & King's College London & $\begin{array}{l}\text { Centre of Human \& Aerospace Physiological Sciences, Division } \\
\text { of Immunology, Infection and Inflammatory Diseases, Division of } \\
\text { Transplantation Immunology \& Mucosal Biology and Division of } \\
\text { Imaging Sciences and Biomedical Engineering }\end{array}$ & Bioscience \\
\hline & UCL & $\begin{array}{l}\text { Department of Biochemical Engineering, Division of } \\
\text { Biosciences and Institute of Cardiovascular Science }\end{array}$ & Bioscience \\
\hline & UCL & Science and Technology Studies \& Department of Computer Science & $\begin{array}{l}\text { IT, systems sciences \& computer } \\
\text { software engineering }\end{array}$ \\
\hline & Oxford University & $\begin{array}{l}\text { Department of Biochemistry \& Sir William Dunn School of } \\
\text { Pathology }\end{array}$ & Bioscience \\
\hline & Imperial College London & Department of Bioengineering \& Department of Life Science & Bioscience \\
\hline \multirow[t]{2}{*}{2016} & UCL & $\begin{array}{l}\text { MRC Lab for Molecular Cell Biology \& Department of Medical } \\
\text { Physics and Bioengineering }\end{array}$ & Bioscience \\
\hline & University of Warwick & Department of Mathematics \& Department of Statistics & Mathematics \\
\hline
\end{tabular}


Table B4: Athena SWAN sample summary statistics

\begin{tabular}{|c|c|c|c|c|c|c|c|c|}
\hline & \multicolumn{4}{|c|}{ Non-Prof } & \multicolumn{4}{|c|}{ Prof } \\
\hline & (1) & (2) & (3) & (4) & (5) & (6) & (7) & (8) \\
\hline & $\begin{array}{c}\text { Accredited } \\
\text { Departments }\end{array}$ & $\begin{array}{c}\text { Non- } \\
\text { Accredited } \\
\text { Departments }\end{array}$ & Diff & P-value & $\begin{array}{c}\text { Accredited } \\
\text { Departments }\end{array}$ & $\begin{array}{c}\text { Non- } \\
\text { Accredited } \\
\text { Departments }\end{array}$ & Diff & P-value \\
\hline Prop. of Females & 0.187 & 0.173 & 0.014 & {$[0.020]$} & 0.102 & 0.088 & 0.015 & {$[0.031]$} \\
\hline Real annual wages in logs & 10.87 & 10.87 & 0.002 & [0.349] & 11.27 & 11.28 & -0.007 & [0.095] \\
\hline Real annual wages & 53,402 & 53,396 & 5.569 & [0.969] & 80,074 & 80,581 & -507 & [0.159] \\
\hline Average age & 43 & 43 & 0.005 & {$[0.716]$} & 52 & 52 & 0.032 & [0.057] \\
\hline Average Tenure & 11 & 10 & 0.07 & {$[0.000]$} & 16 & 16 & 0.000 & [0.983] \\
\hline Number of Individuals & 8,055 & 1,085 & & & 4,575 & 435 & & \\
\hline $\begin{array}{l}\text { Notes: Source HESA (2009 } \\
\text { 2016. Column } 2 \text { presents st } \\
\text { consist of only } 11 \text { cost cent } \\
2016 \text { CPI index. Annual wa } \\
\text { presents the difference betw }\end{array}$ & $\begin{array}{l}\text { 16) dataset. } \\
\text { mary statisti } \\
\text { in the STE } \\
\text { s are censore } \\
\text { the mean o }\end{array}$ & $\begin{array}{l}\text { mn } 1 \text { present } \\
\text { departments } \\
\text { ipline exclu } \\
\text { e top and the } \\
\text { ccredited san }\end{array}$ & the & orded & $\begin{array}{l}\text { its that have } \\
\text { la accreditat } \\
\text { I sciences c } \\
\text { ent extreme } \\
\text { for non-pro }\end{array}$ & $\begin{array}{l}\mathrm{d} \text { an Athena } \\
\text { given year a } \\
\text { e. Log real a } \\
\text { affecting me } \\
\text { nd professors }\end{array}$ & $\begin{array}{l}\text { ditatio } \\
\text { ear } 20 \\
\text { wages } \\
\text { rries. C }\end{array}$ & $\begin{array}{l}\text { f the year } \\
\text { he sample } \\
\text { sted using } \\
\text { ns } 5 \text { and } 7\end{array}$ \\
\hline
\end{tabular}


Years before/after Athena time dummies X

Female

Year (-5) X Female

Year (-4) X Female
Year (-3) X Female
Year (-2) X Female
Year (0) X Female
Year (1) X Female
Year (2) X Female
Year (3) X Female
Year (4) X Female
Year (5) X Female
Year (6) X Female

$-0.001$

(0.008)

0.002

$(0.007)$

0.001

$(0.005)$

0.001

$(0.004)$

$-0.001$

$(0.003)$

$-0.005$

$(0.005)$

0.000

(0.005)

0.002

(0.006)

$-0.000$

(0.007)

$-0.017^{* *}$

(0.008)

$-0.019 * *$

(0.009)

$9.885^{* * *}$

Constant

(0.039)

0.473

R-squared
$-0.014$

0.005

0.011

(0.009)

$0.013^{*}$

(0.007)

$0.020^{* *}$

(0.009)

$0.026^{* * *}$

(0.010)

$0.022 *$

$0.024 *$

$0.037 * *$

(0.017)

$0.041^{* *}$

10.234 ***

(0.108)

0.295

\begin{tabular}{lcc}
\hline Individual controls & Yes & Yes \\
University FE & Yes & Yes \\
Subject FE & Yes & Yes \\
Year FE & Yes & Yes \\
Uni X Time FE & Yes & Yes \\
Observations & 37,190 & 23,035 \\
Number of Individuals & 8,055 & 4,575 \\
\hline
\end{tabular}

Note: Source HESA dataset. The table presents estimates from equation 2 plotted in figure 3 for STEM departments. The dependent variable is log real annual wages adjusted using 2016 CPI index. Annual wages are censored at the top and the bottom 1\% salaries earned to prevent extreme outliers affecting mean salaries. Year before Athena accreditation is the reference year. The coefficients indicate the relative impact on wages of males and female relative to the reference year. Individual controls include age, age squared, tenure, tenure squared, par-time indicator, Robust standard errors are clustered at the Individual level are shown in parentheses. ${ }^{* * *} \mathrm{p}<0.01,{ }^{* *} \mathrm{p}<0.05,{ }^{*} \mathrm{p}<0.1$ 
